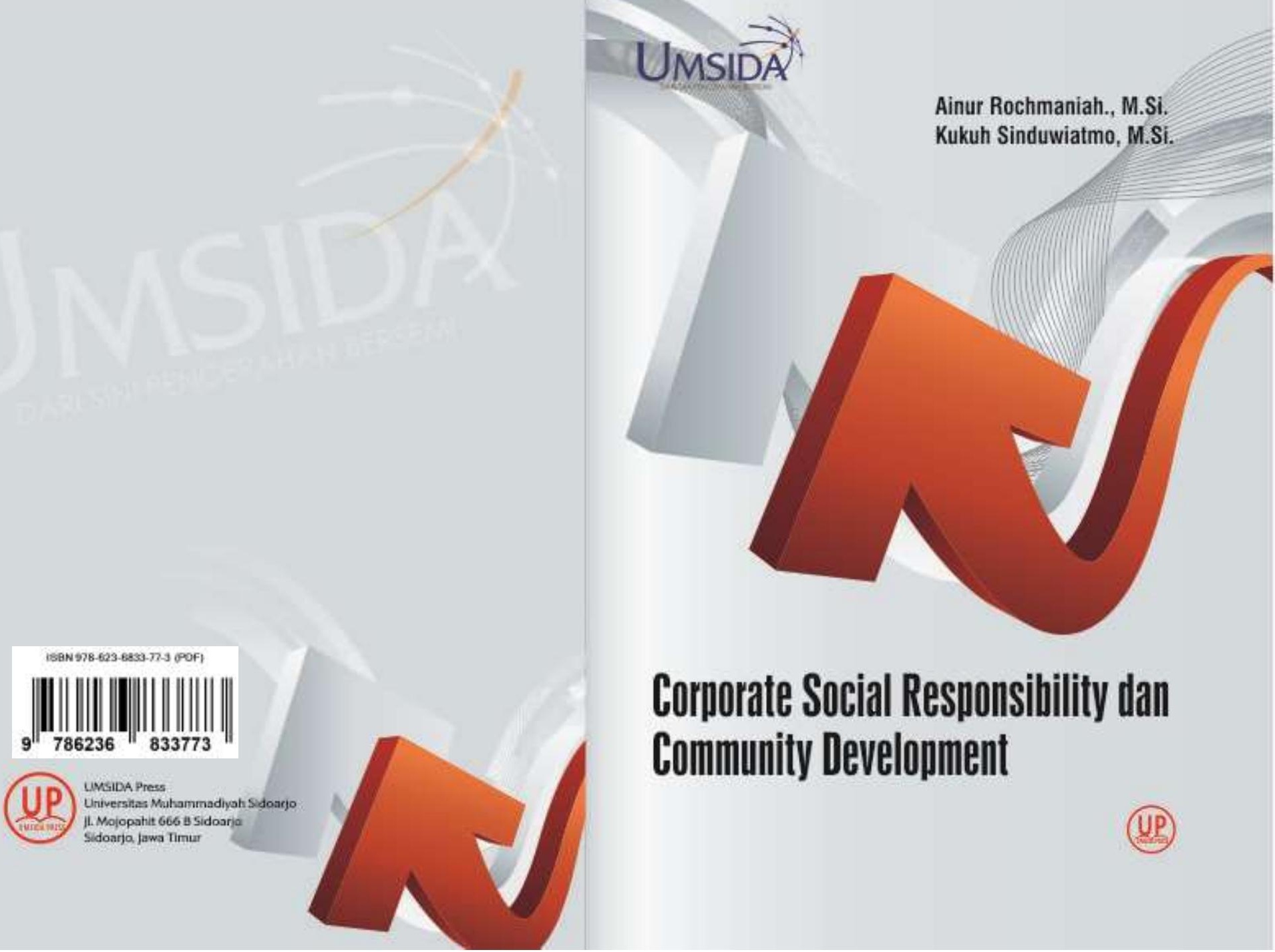




\section{BUKU AJAR \\ CORPORATE SOSIAL RESPONSIBILITY \\ DAN COMMUNITY DEVELOPMENT}

Oleh

Ainur Rochmaniah, M.Si

Kukuh Sinduwiatmo, M.Si

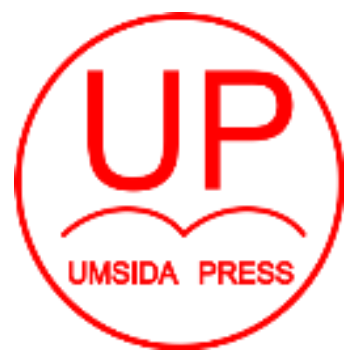

UNIVERSITAS MUHAMMADIYAH SIDOARJO 2020 


\section{BUKU AJAR \\ CORPORATE SOCIAL RESPONSIBILITY DAN \\ COMMUNITY DEVELOPMENT}

\section{Penulis:}

Ainur Rochmaniah., S.Sos. M.Si

Kukuh Sinduwiatmo., S.Sos. M.Si

\section{ISBN :}

978-623-6833-77-3

\section{Editor:}

Dr. Isnaini Rodiyah, M.Si

\section{Design Sampul dan Tata Letak:}

Mochammad Nashrullah, S.Pd.

Amy Yoga Prajati, S.Kom.

Penerbit:

UMSIDA Press

Anggota IKAPI No. 218/Anggota Luar Biasa/JTI/2019

Anggota APPTI No. 0020181092017

Redaksi

Universitas Muhammadiyah Sidoarjo

Jl. Mojopahit No 666B

Sidoarjo, Jawa Timur

Cetakan Pertama, September 2020

CHak Cipta dilindungi undang undang

Dilarang memperbanyak karya tulis ini dengan sengaja, tanpa ijin tertulis dari penerbit. 


\section{KATA PENGANTAR}

Puji syukur kami panjatkan kehadirat Allah SWT, atas rahmat dan karunia-Nya Buku Ajar Corporate Social Responsibility dan Community Development dapat diselesaikan dengan baik dan tanpa halangan yang berarti. Shalawat serta salam selalu kami sampaikan kepada junjungan Nabi Muhammad SAW.

Tim penulis mengucapkan terimakasih kepada:

1. Dr. Wisnu Panggah Setiyono, Dekan Fakultas Bisnis, Hukum dan Ilmu Sosial yang memberikan arahan dan motivasi kepada penulis dalam menyelesaikan buku ajar ini.

2. Rekan-rekan dosen pengampu Mata Kuliah Corporate Social Responsibility dan Community Development yang telah berbagi pengalaman dalam mengampu mata kuliah tersebut.

Saran dan kritik sangat penulis harapkan untuk mewujudkan buku ajar Corporate Social Responsibility dan Community Development yang lebih baik dan tentunya sesuai dengan amanat peraturan yang berlaku. Terimakasih.

Tim Penulis 


\section{DAFTAR ISI}

\section{KATA PENGANTAR}

DAFTAR ISI

DAFTAR TABEL

BAB 1 CORPORATE SOCIAL RESPONSIBILITY 1

1.1. Deskrpsi Singkat 1

1.2. Pengertian Corporate Social Responsibility 1

1.3. Good Corporate Governance (GCG) 3

1.4. Hubungan antara Good Corporate Governance 10 dengan Corporate Social Responsibility

1.5. Kebijakan Pemerintah Terhadap Corporate 11 Social Responsibility di Indonesia

1.6. Manfaat Corporate Social Responsibility 15

1.7. Penelitian-penelitian 16

$\begin{array}{ll}\text { KESIMPULAN MATERI } & 19\end{array}$

KOMPETENSI DASAR 20

$\begin{array}{ll}\text { INDIKATOR } & 21\end{array}$

$\begin{array}{ll}\text { SOAL } & 21\end{array}$

$\begin{array}{ll}\text { DAFTAR PUSTAKA } & 22\end{array}$

$\begin{array}{lll}\text { BAB II TRIPLE BOTTOM LINE } & 23\end{array}$

2.1 Deskripsi Singkat 23 
2.2. Triple Bottom Line 23

2.3. Piramida CARROL 26

2.4. Penelitian-penelitian pelaksanaan Triple 33 Bottom Line dalam Corporate Social Responsibility

KESIMPULAN MATERI $\quad 37$

KOMPETENSI 38

INDIKATOR 39

$\begin{array}{ll}\text { SOAL } & 39\end{array}$

DAFTAR PUSTAKA 39

BAB III PELAKSANAAN CORPORATE SOCIAL RESPONSIBILITY 41

3.1 Deskripsi Singkat 41

3.2 Implementasi dan Pola Model Corporate Social 41 Responsibility

3.3 Strategi Pengelolaan CSR 45

3.4 Motivasi dan Paradigma CSR 48

3.5 Pro dan Kontra CSR 50

3.6 Penelitian-penelitian Implementasi dan Pola 51 Model CSR

KESIMPULAN MATERI 54

KOMPETENSI

$\begin{array}{ll}\text { INDIKATOR } & 55\end{array}$ 
$\begin{array}{ll}\text { SOAL } & 55\end{array}$

DAFTAR PUSTAKA 56

BAB IV BIDANG KERJA CORPORATE SOCIAL 57 RESPONSIBILITY

$\begin{array}{lll}4.1 & \text { Deskripsi } & 57\end{array}$

4.2 Bidang Kerja Corporate Social Responsibility 57

$\begin{array}{lll}4.3 & \text { Bentuk-bentuk CSR } & 57\end{array}$

4.4. Kategori CSR 62

4.5. Penelitian-penelitian Bidang Kerja 70

KESIMPULAN MATERI 76

$\begin{array}{ll}\text { KOMPETENSI } & 77\end{array}$

$\begin{array}{ll}\text { SOAL } & 77\end{array}$

$\begin{array}{ll}\text { DAFTAR PUSTAKA } & 77\end{array}$

BAB V SASARAN KERJA CORPORATE SOCIAL 78 RESPONSIBILITY

$\begin{array}{lll}5.1 & \text { Deskripsi } & 78\end{array}$

5.2 Sasaran Kerja Corporate Social Responsibility 78

5.3. Penelitian-penelitian terkait dengan sasaran 85 kerja CSR

KESIMPULAN MATERI $\quad 89$

$\begin{array}{ll}\text { INDIKATOR } & 90\end{array}$ 
$\begin{array}{ll}\text { SOAL } & 90\end{array}$

$\begin{array}{ll}\text { DAFTAR PUSTAKA } & 91\end{array}$

BAB VI COMMUNITY DEVELOPMENT 93

6.1. Deskripsi 93

6.2. Definisi dan Pengertian Community 93

Development

6.3. Unsur-unsur dalam Community Development 96

6.4. Tiga Jenis Program Community Development 97

6.5. Community Development dan Partisipasi 98

Masyarakat

6.6. Strategi dan Perencanaan Community 100

Development

$\begin{array}{ll}\text { 6.7. Penelitian-penelitian } & 103\end{array}$

$\begin{array}{ll}\text { KESIMPULAN MATERI } & 107\end{array}$

$\begin{array}{ll}\text { INDIKATOR } & 107\end{array}$

$\begin{array}{ll}\text { SOAL } & 108\end{array}$

$\begin{array}{ll}\text { DAFTAR PUSTAKA } & 109\end{array}$ 
BATANG TUBUH DAN

SUB-CAPAIAN PEMBELAJARAN MATA KULIAH

\begin{tabular}{|c|c|}
\hline BAB & Sub-Capaian Pembelajaran Mata Kuliah \\
\hline $\begin{array}{l}\text { BAB I } \\
\text { CORPORATE } \\
\text { SOCIAL } \\
\text { RESPONSIBILITY }\end{array}$ & $\begin{array}{l}\text { 1. Mahasiswa mampu memahami pengertian } \\
\text { Corporate Social Responsibility } \\
\text { 2. Mahasiswa mampu memahami Good Corporate } \\
\text { Governance } \\
\text { 3. Mahasiswa mampu memahami hubungan antara } \\
\text { Corporate Social Responsibility dan Good Corporate } \\
\text { Governance } \\
\text { 4. Mahasiswa mampu memahami kebijakan } \\
\text { Pemerintah terhadap Corporate Social Responsibility } \\
\text { 5. Mahasiswa mampu memahami manfaat Corporate } \\
\text { Social Responsibility }\end{array}$ \\
\hline $\begin{array}{l}\text { BAB II } \\
\text { TRIPLE BOTTOM } \\
\text { LINE }\end{array}$ & $\begin{array}{l}\text { 1. Mahasiswa mampu mengidentifikasi konsep people } \\
\text { dalam pelaksanaan Corporate Social Responsibility } \\
\text { 2. Mahasiswa mampu mengidentifikasi konsep planet } \\
\text { dalam pelaksanaan Corporate Social Responsibility } \\
\text { 3. Mahasiswa mampu mengidentifikasi konsep Profit } \\
\text { dalam pelaksanaan Corporate Social Responsibility } \\
\text { 4. Mahasiswa mampu mengidentifikasi konsep } \\
\text { Piramida Carrol dalam pelaksanaan Corporate Social } \\
\text { Responsibility }\end{array}$ \\
\hline $\begin{array}{l}\text { BAB III } \\
\text { PELAKSANAAN } \\
\text { CORPORATE } \\
\text { SOCIAL } \\
\text { RESPONSIBILITY }\end{array}$ & $\begin{array}{l}\text { 1. Mahasiswa mampu membandingkan implementasi } \\
\text { dan pola model Corporate Social Responsibility } \\
\text { 2. Mahasiswa mampu membandingkan strategi } \\
\text { pengelolaan Corporate Social Responsibility } \\
\text { 3. Mahasiswa mampu membandingkan paradigma } \\
\text { pelaksanaan Corporate Social Responsibility } \\
\text { 4. Mahasiswa mampu menjelaskan pro dan kontra } \\
\text { Corporate Social Responsibility }\end{array}$ \\
\hline
\end{tabular}




\begin{tabular}{|c|c|}
\hline $\begin{array}{l}\text { BAB IV } \\
\text { BIDANG KERJA } \\
\text { CORPORATE } \\
\text { SOCIAL } \\
\text { RESPONSIBILITY }\end{array}$ & $\begin{array}{l}\text { 1. Mahasiswa mampu mengidentifikasi bidang-bidang } \\
\text { kerja pendidikan, kesehatan, lingkungan dan } \\
\text { ekonomi } \\
\text { 2. Mahasiswa mampu mengaplikasikan bidang-bidang } \\
\text { kerja pendidikan, kesehatan, lingkungan dan } \\
\text { ekonomi dalam Corporate Social Responsibility }\end{array}$ \\
\hline $\begin{array}{l}\text { BAB V } \\
\text { SASARAN KERJA } \\
\text { CORPORATE } \\
\text { SOCIAL } \\
\text { RESPONSIBILITY }\end{array}$ & $\begin{array}{l}\text { 1. Mahasiswa mampu memahami Corporate Social } \\
\text { Responsibility terhadap karyawan, pelanggan dan } \\
\text { komunitas } \\
\text { 2. Mahasiswa mampu membandingkan Corporate } \\
\text { Social Responsibility terhadap karyawan, pelanggan } \\
\text { dan komunitas }\end{array}$ \\
\hline $\begin{array}{l}\text { BAB VI } \\
\text { COMMUNITY } \\
\text { DEVELOPMENT }\end{array}$ & $\begin{array}{l}\text { 1. Mahasiswa mampu memahami pengertian } \\
\text { community development } \\
\text { 2. Mahasiswa mampu memahami unsur-unsur dalam } \\
\text { community development } \\
\text { 3. Mahasiswa mampu membandingkan tiga jenis } \\
\text { program community development } \\
\text { 4. Mahasiswa mampu memahami community } \\
\text { development dan partisipasi masyarakat } \\
\text { 5. Mahasiswa mampu mengaplikasikan strategi dan } \\
\text { perencanaan community development }\end{array}$ \\
\hline
\end{tabular}




\section{BAB 1}

\section{CORPORATE SOCIAL RESPONSIBILITY}

\subsection{Deskrpsi Singkat:}

Bab 1 membahas mengenai pengertian Corporate Social Responsibility (CSR) menurut beberapa pakar CSR dan lembaga-lembaga nasional dan internasional, hubungan antara Good Corporate Governance (GCG) dengan CSR, kebijakan-kebijakan dari Pemerintah RI terkait pelaksanaan CSR oleh perusahaan-perusahaan di Indonesia dan manfaat CSR bagi masyarakat, perusahaan dan pemerintah

\subsection{Pengertian Corporate Social Responsibility}

Corporate Social Responsibility atau disingkat CSR, dan dalam terjemah Bahasa Indonesia berarti tanggungjawab sosial perusahaan telah dilakukan oleh perusahaan baik perusahaan kecil, sedang maupun besar sejak bertahun-tahun yang lalu, dengan berbagai bentuk dan jenisnya, dan untuk sebagian atau semua stakeholders (pemangku kepentinggan). Tetapi definisi dan pengertian CSR sendiri masih menjadi perdebatan dan mempunyai banyak penafsiran dari berbagai sudut pandang keilmuan ekonomi, sosial, Public Relations, agama, lingkungan dan sebagainya. 
Berikut berbagai definisi CSR dari beberapa ahli dan lembaga-lembaga internasional:

a. The World Business Council for Sustainable Development (WBCSD), merumuskan CSR sebagai "The continuing commitment by business to be have ethically and contribute to economic development while improving the quality of life of the workforce and their families as well as of the local community anda society at large to improve their quality of life". (Azheri, 2012:21)

(Komitmen dari bisnis/perusahaan untuk berperilaku etis dan berkontribusi terhadap pembangunan ekonomi yang berkelanjutan, seraya meningkatkan kualitas hidup karyawan dan keluarganya, komunitas lokal dan masyarakat lainnya)

b. Indonesia Business Links, CSR adalah "The commitment of business to minimize its negative impact and maximize its positive contributions to all stakeholders in connection in economic, social and environmental aspects to achieve sustainable development. " (Lako, 2011:45)

(Komitmen bisnis untuk mengurangi dampak negatif dan memaksimalkan kontribusi positif untuk semua stakeholders (pemangku kepentingan) dalam aspek ekonomi, sosial dan lingkungan hidup untuk mencapai pembangunan yang berkelanjutan). 
c. Kotler \& Lee (2005) mendefinisikan CSR sebagai komitmen korporasi untuk meningkatkan kesejahteraan masyarakat sekitar melalui kebijakan praktik bisnis dan pemberian kontribusi sumber daya korporasi

d. Michael Hopkins, menyatakan CSR berkaitan dengan perlakuan perusahaan terhadap stakeholders baik yang berada didalam mapun diluar perusahaan, termasuk lingkungan, secara etis atau bertanggungjawab dengan memperlakukan stakeholders dengan cara yang bisa diterimanya. (Azheri, 2012:26)

e. European Union memberikan definisi CSR yaitu sebuah konsep dengan mana perusahaan mengintegrasikan perhatian terhadap sosial dan lingkungan dalam operasi bisnis mereka dan dalam interaksinya dengan para pemangku kepentingan (stakeholders) berdasarkan prinsip kesukarelaan. (Azheri, 2012:20-21)

Dari semua definisi diatas, dapat ditarik penjelasan, bahwa pengertian CSR mencakup hal-hal berikut:

a. Pelaksanaan CSR untuk meningkatkan kesejahteraan masyarakat secara berkelanjutan

b. Sasaran CSR adalah stakeholders yang terdiri dari stakeholders internal dan eksternal perusahaan 
c. Bidang kerja CSR meliputi manusia dan lingkungannya

\subsection{Good Corporate Governance (GCG)}

Corporate Governance adalah rangkaian proses terstruktur yang digunakan untuk mengelola mengarahkan atau memimpin bisnis dan usaha-usaha korposari dengan tujuan untuk meningkatkan nilai-nilai perusahaan serta kontinuitas usaha. Berikut beberapa pemahaman tentang Corporate Governance.

1. Forum for Corporate Governance in Indonesia (FCGI) dalam Hery (2010) mendefinisikan Corporate Governance adalah seperangkat peraturan yang mengatur hubungan antara pemegang saham, pengurus (pengelola) perusahaan, pihak kreditur, pemerintah, karyawan, serta para pemegang kepentingan internal dan eksternal lainnya yang berkaitan dengan hak-hak dan kewajiban mereka atau dengan kata lain suatu sistem yang mengendalikan perusahaan. Tujuan Corporate Governance adalah menciptakan nilai tambah bagi semua pihak yang berkepentingan (stakeholders)

2. Sutedi (2011) mendefinisikan Corporate Governance yaitu suatu proses dan struktur yang digunakan oleh organ perusahaan (pemegang saham/pemilik modal, komisaris/ dewan pengawas dan direksi) untuk meningkatkan keberhasilan usaha dan 
akuntabilitas perusahaan guna mewujudkan nilai pemegang saham dalam jangka panjang dengan tetap memperhatikan kepentingan stakeholder lainnya, berlandaskan peraturan perundangundangan dan nilai-nilai etika.

3. Pasal 1 Surat KEPMEN BUMN No. KEP-117/M$\mathrm{MBU} / 2002 \mathrm{tgl} 31$ Juli 2002 tentang penerapan GCG pada BUMN (Efendi, 2009), menyatakan: Corporate Governance adalah suatu proses dan struktur yang digunakan oleeh organ BUMN untuk meningkatkan keberhasilan usaha dan akuntabilitas perusahaan guna mewujudkan nilai pemegang saham dalam jangka panjang dengan tetap memperhatikan kepentingan stakeholder lainnya, berlandaskan peraturan perundangan dan nilai-nilai etika.

Berdasarkan definisi-definisi diatas, GCG dapat diartikan sebagai seperangkat sistem yang mengatur dan mengen-dalikan perusahaan untuk menciptakan nilai tambah (value added) bagi para pemangku kepentingan. Hal ini karena GCG dapat mendorong terbentuknya pola kerja manajemen yang bersih, transparan, dan profesional. Penerapan GCG di perusahaan akan menarik minat para investor, baik dari dalam maupun luar negeri. Hal ini sangat penting bagi perusahaan yang ingin mengembangkan usahanya, seperti melakukan investasi baru. 


\subsubsection{Prinsip-Prinsip Good Corporate Governance}

Menurut Peraturan Bank Indonesia No. 8/4/PBI/2006 tentang Pelaksanaan Good Corporate Governance, diantaranya Transparency, Accountability, Reponsibility, Independency dan Fairness (TARIF). Prinsip-prinsip yang terkandung dalam Good Corporate Governance, dapat dijabarkan sebagai berikut:

1. Transparency (Keterbukaan)

Transparency yaitu keterbukaan dalam memberikan informasi yang sesuai dengan kondisi serta dalam proses mencapai kesepakatan program. Disini, perusahaan menyiapkan informasi yang memadai, teliti, dan memberikan pada saat yang tepat kepada pihak yang mempunyai perhatian kepada lembaga usaha tersebut. Disamping itu, lembaga usaha juga memberikan kemudahan akses informasi kepada para pemegang saham, pada saat dibutuhkan. Transparansi diperlukan perusahaan karena berhubungan dengan proses decision making dalam menganalisis konsekuensi dan profit dari modal yang ditanam di perusahaan.

Informasi yang belum memenuhi kebutuhan pihak luar, akan memberikan persepsi negatif bahwa perusahaan kekurangan dana operasional dan akan membatasi kemampuan investor untuk memperhitungkan nilai dan resiko serta pertambahan dari perubahan modal (volatility of capital). 


\section{Accountability (Akuntabilitas)}

Accountability (akuntabilitas) lebih dipahami sebagai distribusi wewenang dan tanggungjawab diantara manajer perusahaan dan pemegang saham yang diwakili dewan direksi. Penerapan prinsip secara efektif akan meminimalkan benturan kepentingan peran diantara para pimpinan level menengah.

\section{Responsibility (Pertanggungjawaban)}

Responsibility (pertanggungjawaban) adalah pelaku usaha dalam mengelola perusahaan sudah sesuai dengan hukum yang berlaku. Peraturan yang berlaku diantaranya terkait masalah pajak, industrial relations, perlindungan lingkungan hidup, kesehatan/keselamatan kerja, standar penggajian, dan persaingan yang sehat.

\section{Independency (Kemandirian)}

Independency (kemandirian) adalah kesiapan dan kemampuan perusahaan untuk berdiri sendiri, tidak ada campur tangan dari pihak manapun baik dari luar maupun dalam perusahaan. Hal ini berarti perusahaan telah mengelola sesuai dengan hukum yang berlaku dan asas korporasi yang kondusi.

5. Fairness atau kesetaraan dan kewajaran

Fairness atau kesetaraan dan kewajaran, terkait dengan perusahaan yang memperlakukan secara adil dan layak 
sesuai dengan perjanjian dan bukum yang berlaku, sehingga semua kekayaan perusahaan diatur secara baik dan penuh pertimbangan dan berdampak pada proteksi kepentingan pemegang saham secara jujur dan adil. Intinya, kesetaraan adalah perlakuan yang adil dan setara dalam memenuhi hak-hak stakeholders, terutama untuk pemegang saham minoritas. Investor harus mengetahui hak-hak kepemilikan dan aturan yang berlaku untuk melindungi haknya tersebut.

Good Corporate Governance akan memberikan empat manfaat besar (Wilson Arafat, 2008:10), yaitu:

1. Meningkatkan kinerja perusahaan melalui terciptanya proses pengambilan keputusan yang lebih baik, meningkatkan efisiensi operasional perusahaan serta lebih meningkatkan pelayanan kepada stakeholders.

2. Meningkatkan corporate value.

3. Meningkatkan kepercayaan investor.

4. Pemegang saham akan merasa puas dengan kinerja perusahaan karena sekaligus akan meningkatkan shareholder's value dan dividen.

\subsubsection{Unsur-unsur Good Corporate Governance}

Dalam penerapan Good Corporate Governance diperlukan unsur-unsur yang mendukung (Sutedi, 2011), yaitu: 
a. Corporate Governance - Internal perusahaan Unsur-unsur yang berasal dari dalam perusahaan adalah:

1) Pemegang saham

2) Direksi

3) Dewan Komisaris

4) Manajer

5) Karyawan

6) Sistem remunerasi berdasarkan kinerja

7) Komite audit

Unsur-unsur yang selalu diperlukan didalam perusahaan, antara lain meliputi:

1) Keterbukaan dan kerahasiaan

2) Transparansi

3) Akuntabilitas

4) Kesetaraan

5) Aturan dari code of conduct

b. Corporate Governance - External perusahaan Unsur-unsur yang berasal dari luar perusahaan adalah:

1) Kecukupan undang-undang dan perangkat hukum

2) Investor 
3) Institusi penyedia informasi

4) Akuntan Publik

5) Institusi yang memihak kepentingan publik bukan golongan

6) Pemberi pinjaman

7) Lembaga yang mengesahkan legalitas

Unsur-unsur yang selalu diperlukan di luar perusahaan antara lain meliputi:

1) Aturan dari code of conduct

2) Kesetaraan

3) Akuntabilitas

4) Jaminan hukum

Perilaku partisipasi pelaku Corporate Governance yang berada di dalam rangkain unsur-unsur internal maupun eksternal menentukan kualitas Corporate Governance.

\subsubsection{Tujuan Good Corporate Governance yaitu}

a. Memaksimalkan nilai perusahaan dengan cara meningkatkan prinsip keterbukaan, akuntabilitas, dapat dipercaya, bertanggungjawab, dan adil agar perusahaan memiliki daya saing yang kuat, baik secara nasional maupun internasional.

b. Mendorong pengelolaan perusahaan secara profesional, transparan dan efisiensi, serta 
memberdayakan fungsi dan meningkatkan kemandirian organ

c. Mendorong agar organ dalam membuat keputusan dan menjalankan tindaka dilandasi nilai moral yang tinggi dan kepatuhan terhadap peraturan perundangan yang berlaku, serta kesadaran akan adanya tanggungjawab sosial terhadap stakeholders maupun kelestarian lingkungan di sekitar perusahaan.

d. Meningkatkan kontribusi perusahaan dalam perekonomian nasional

e. Meningkatkan iklim investasi nasional

f. Mensukseskan program privatisasi

\subsection{Hubungan antara Good Corporate Governance dengan} Corporate Social Responsibility

Good Corporate Governance (GCG) mempunyai prinsipprinsip yang terdiri dari Transparency, Accountability, Reponsibility, Independency dan Fairness atau disingkat dengan TARIF dan mempunyai benang merah dengan kegiatan pelaksanaan Corporate Social Responsibility (CSR) perusahaan, terutama terkait dengan prinsip responsibility atau pertanggungjawaban. Pengertian pertanggungjawaban mengacu pada ketaatan perusahaan terhadap peraturan perundangan yang berlaku, termasuk didalamnya perlindungan lingkungan 
di sekitar perusahaan, tentang hak konsumen juga kesehatan dan keselamatan kerja karyawan. Dengan prinsip ini, perusahaan telah memperhatikan kepentingan stakeholders atau pemangku kepentingan sebagai bentuk konsekunsi dari operasional perusahaannya.

Sebagai salah satu bentuk implementasi dari konsep Good Corporate Governance (GCG), prinsip responsibility harus dapat diterapkan dalam operasional perusahaan. Dengan menerapkan prinsip tersebut, perusahaan dianggap sebagai perusahaan yang sehat. Perusahaan yang mampu dan mau melakukan kegiatan kemanusiaan dengan prinsip bahwa permasalahan stakeholders adalah juga milik perusahaannya, menyadari bahwa kegiatan sehari-hari perusahaan mempunyai dampak baik positif maupun negatif terhadap masyarakat di sekitarnya.

Responsibility atau pertanggungjawaban perusahaan terhadap stakeholders nya tidak hanya dilakukan satu atau dua hari saja, atau beberapa kali dalam satu tahun. Keberlanjutan adalah sisi lain dari kegiatan ini, artinya perusahaan harus merancang dengan benar setiap langkahnya, karena semua kebijakan yang diambil perusahaan mempunyai pengaruh yang besar untuk jangka panjang, salah satunya adalah citra atau image perusahaan. Perusahaan yang memberikan perhatian dan kerjasama yang baik dengan masyarakat dan stakeholders yang lain, akan mendapatkan kepercayaan 
baik dari masyarakat sekitar, konsumen, karyawan maupun Pemerintah setempat.

\subsection{Kebijakan Pemerintah Terhadap Corporate Social} Responsibility di Indonesia

Pemerintah sebagai pemegang dan pelaksana kebijakan untuk menangani masalah masyarakat dari berbagai aspek sosial, ekonomi, kesehatan dan lingkungan mempunyai keterbatasan baik dari sisi sumber daya manusia (SDM) maupun sumber daya alam (SDA) dan juga dana. Terkait hal tersebut, Pemerintah kemudian mengeluarkan kebijakan-kebijakan dalam pelaksanaan CSR.

Dibawah ini adalah kebijakan-kebijakan Pemerintah untuk mengatur kegiatan CSR:

1) Undang-Undang Minyak dan Gas Bumi Nomor 22 Tahun 2001. Khusus bagi perusahaan yang operasionalnya mengelola Sumber Daya Alam (SDA) dalam hal ini minyak dan gas bumi, terikat oleh Undang-undang Nomor 22 Tahun 2001, tentang Minyak dan Gas Bumi. Berdasarkan Undang-undang tersebut, perusahaan wajib melaksanakan kegiatan pengembangan masyarakat dan menjamin hak-hak masyarakat adat yang berada di sekitar perusahaan.

2) Penjelasan Pasal 15 huruf $b$ Undang-Undang Nomor 25 tahun 2007 tentang penanaman modal (UUPM) yang menegaskan bahwa " tanggung jawab sosial 
perusahaan adalah tanggung jawab yang melekat pada setiap perusahaan penanaman modal untuk menciptakan hubungan yang serasi, seimbang dan sesuai dengan lingkungan, nilai, norma, dan budaya masyarakat setempat.

3) Pasal 1 Ayat 3 Undang-Undang Nomor 40 tahun 2007 tentang perseroan terbatas (UUPT) juga menegaskan bahwa " tanggung jawab sosial dan lingkungan adalah komitmen perusahaan untuk berperan serta dalam pembangunan ekonomi berkelanjutan guna meningkatkan kualitas kehidupan dan lingkungan yang bermanfaat, baik bagi perusahaan sendiri, komunitas setempat, maupun masyarakat pada umumnya".

4) Keputusan Menteri BUMN Tentang Program Kemitraan Bina Lingkungan (PKBL). Berdasarkan Peraturan Menteri Negara BUMN, Per05/MBU/2007 Pasal 1 ayat (6) dijelaskan bahwa Program Kemitraan BUMN dengan Usaha Kecil, yang selanjutnya disebut Program Kemitraan, adalah program untuk meningkatkan kemampuan usaha kecil agar menjadi tangguh dan mandiri melalui pemanfaatan dana dari bagian laba BUMN. Sedangkan pada pasal 1 ayat (7) dijelaskan bahwa Program Bina Lingkungan, yang selanjutnya disebut Program BL, adalah program pemberdayaan kondisi sosial masyarakat oleh BUMN melalui pemanfaatan dana dari bagian laba BUMN. Adapun ruang lingkup 
bantuan Program BL BUMN, berdasarkan Permeneg BUMN, Per-05/MBU/2007 Pasal 11 ayat (2) huruf e adalah: a) Bantuan korban bencana alam; b) Bantuan pendidikan dan/atau pelatihan; c) Bantuan peningkatan kesehatan; d) Bantuan pengembangan prasarana dan/atau sarana umum; e) Bantuan sarana ibadah; f) Bantuan pelestarian alam.

Mewajibkan CSR merupakan salah satu upaya pemerintah untuk menyeimbangkan pertumbuhan dan pemerataan ekonomi, melestarikan lingkungan hidup, dan memberikan kesempatan kepada perusahaan untuk berempati terhadap kondisi sosial masyarakat sekitar. Dengan dikukuhkannya UU no.40 tahun 2007, kedudukan CSR sebagai salah satu kewajiban perusahaan semakin kuat.

Hal ini yang kemudian memunculkan perdebatan bahwa perusahaan melakukan CSR dengan terpaksa karena UU No 40 Tahun 2007 yang tidak mengikat dan perusahaan yang melaksanakan CSR dengan kerelaan, karena perusahaan telah memberikan dampak negatif berupa limbah (suara, bau, proses produksi, asap, dan lain sebagainya) kepada masyarakat sekitar.

Dari paparan diatas, perusahaan kemudian mengalihkan dasar pelaksanaan CSR pada Guidance ISO 26000. Standar ISO ini sebagai pedoman praktis bagi lembaga sektor publik, swasta dan privat dalam melaksanakan Social Responsibility. 
ISO 26000 meliputi aspek-aspek berikut :

a) ISO 26000 menyediakan pedoman mengenai tanggung jawab sosial untuk seluruh jenis lembaga tanpa memperhatikan tingkatan dan letaknya.

b) ISO 26000 menggerakkan lembaga untuk melakukan kegiatan lebih dari kewajibannya.

c) ISO 26000 melengkapi instrumen dan ide lain yang berkaitan dengan tanggung jawab sosial.

d) Melakukan publisitas informasi tentang CSR dan meningkatkan pemahaman mengenai CSR.

e) Tidak melakukan kegiatan yang bertentangan dengan peraturan baik nasional maupun internasional dan selalu mendukung pemerintah dalam melaksanakan CSR

f) Prinsip patuh pada hukum, taat terhadap instrumen internasional, prinsip akuntabilitas, prinsip transparasi, prinsip sustainability development, prinsip ethical conduct, prinsip menghormati hak asasi manusia, prinsip pendekatan dengan pencegahan dan prinsip menerima keanekaragaman.

\subsection{Manfaat Corporate Social Responsibility}

Menurut Branco dan Rodrigues dalam Mursitama dkk (2011: 27-31), membagi dua manfaat CSR bila dikaitkan dengan keunggulan kompetitif (competitive advantage) 
dari sebuah perusahaan. Yaitu dari sisi internal maupun eksternal.

1.6.1. Manfaat Internal CSR, yaitu :

1) Peningkatan kompetensi sumber daya manusia dengan mengadakan kegiatan pengembangan ketrampilan yang dimiliki pegawai, yang berdampak pada efektifitas sistem manajemen sumebr daya manusia. Kegiatan ini dapat menaikkan kesetiaan dan dukungan dari pegawai

2) Perusahaan lebih peduli terhadap lingkungan dengan melakukan tindakan meminimalisir bahkan meniadakan pencemaran sebagai hasil olahan produksi perusahaan, dan hal ini berdampak pada relasi yang baik dengan supplier.

3) Mewujudkan budaya organisasi, kapabilitas sumber daya manusia, dan organisasi yang baik. Perusahaan dapat mengenalkan CSR dan mempunyai keinginan untuk belajar. Terdapat koordinasi antar fungsi didalam perusahaan, disamping itu ada peningkatan peran serta pegawai di internal perusahaan dan kemampuan pegawai.

4) Pelaksanaan CSr menyebabkan kinerja keuangan menjadi lebih baik dan menaikkan kepemilikan modal.

1.6.2. Manfaat Eksternal CSR, yaitu : 
1) Implementasi CSR akan menaikkan citra perusahaan sebagai lembaga yang menumbuhkan tanggungjawab sosial, hal ini berkaitan dengan service of excelent yang diberikan kepada stakeholders eksternal

2) CSR adalah produk pembeda yang sangat disarankan kepada perusahaan, hal ini berarti produk ini termasuk dalam kategori ramah lingkungan dan hasil dari perusahaan yang telah melaksanakan tanggungjawabnya kepada masyarakat. Dalam hal ini, perusahaan melakukan CSR sesuai dengan kekhasan dari perusahaan tersebut.

3) Pelaksanaan CSR adalah indikator komunikasi yang baik antara perusahaan dengan khalayak. Pada akhirnya, semua pihak mendukung mewujudkan citra dan nama baik perusahaan, dan menunjang hubungan baik antara perusahaan dan karyawan dengan komunitas menjadi lebih terikat dan menyatu.

4) Sumbangan CSR terhadap kinerja perusahaan dapat berupa kesempatan sebagai penghargaan terhadap perilaku yang baik dari perusahaan dan kapasitas perusahaan dalam melindungi dirinya dari dampak yang tidak baik dari perilaku yang buruk.

\subsection{Penelitian-penelitian}


Penelitian terkait dengan pembahasan diatas adalah sebagai berikut:

a. Implementasi prinsip-prinsip good corporate governance dan Corporate Social Responsibility pada PT Waru Teknikatama, hasil riset Inka Ayu Puspitasari. Skripsi. 2020. Tidak diterbitkan

Penelitian ini mempunyai tujuan untuk mengetahui dan menganalisis implementasi prinsip-prinsip good corporate governance dan corporate social responsibility pada PT Waru Teknikatama. Penelitian ini menggunakan pendekatan kualitatif. Informan adalah 3 orang yang memahami kondisi PT Waru Teknikatama. Teknik pengumpulan data dengan wawancara, observasi, dan dokumen. Teknik analisis data dengan model interaktif Miles dan Huberman. Kesimpulan dari penelitian adalah PT Waru Teknikatama menerapkan prinsip transparansi melalui pekerjaan yang tersistem untuk semua bagian; menerapkan prinsip akuntabilitas yang tercermin dalam standar operasional prosedur (SOP), struktur organisasi serta job description setia$\mathrm{p}$ bagian di perusahaan; menerapkan prinsip pertanggungjawaban melalui RPS, melakukan laporan SPT Masa, memberikan bukti potongan pajak PPh 21; memberikan BPJS kesehatan dan Ketenagakerjaan. PT Waru Teknikatama juga mengimplementasikan prinsip independensi melalui international standart, yaitu tidak ada intervensi dari 
vendor terkait proyek dan keluarga tidak ada yang menduduki jabatan penting di perusahaan. Penerapan kewajaran dan keselarasan dengan cara tidak membeda-bedakan karyawan berdasarkan suku, agama, ras dan latar belakang, dan memberikan masa cuti bagi wanita yang melahirkan dan sedang datang bulan.

b. Pengaruh penerapan good corporate governance dan pengungkapan corporate social responsibility pada nilai perusahaan, penelitian oleh Mirsha Amirah Inastri dan Ni Putu Sri Harta Mimba (2017)

Penelitian ini bertujuan untuk mengetahui pengaruh penerapan GCG dan pengungkapan CSR terhadap nilai perusahaan.Jumlah sampel penelitian adalah 33 data perusahaan yang berasal dari 16 perusahaan. Penelitian ini menggunakan metode penentuan sampel purposive sampling dengan kriteria antara lain; perusahaan terdaftar di Bursa Efek Indonesia, mengikuti pemeringkatan CGPI (Corporate Governance Perception Index), dan mengungkapkan sustainability report sesuai standar GRI G-4 periode 2013-2016. Teknik analisis yang digunakan adalah analisis regresi linier berganda.Penelitian ini memperoleh dua hasil yaitu yang pertama, variabel penerapan GCG yang diproksikan dengan skor CGPI berpengaruh positif dan signifikan pada nilai perusahaan karena nilai 
signifikansi uji t sebesar 0,011 lebih kecil dari tingkat signifikansi 0,05. Hasil kedua, variabel pengungkapan CSR yang diproksikan dengan CSRI (Corporate Social Responsibility Index) tidak berpengaruh positif dan tidak signifikan pada nilai perusahaan karena nilai signifikansi uji t sebesar 0,710 lebih besar dari tingkat signifikansi 0,05.

c. Analisis pengaruh penerapan Good Corporate Governance (GCG) dan Corporate Social Responsibility (CSR) terhadap kinerja keuangan (Studi kasus pada bank syariah periode 2012 - 2016), oleh Fadel Muhammad (2017)

Tujuan dari penelitian ini adalah untuk mengetahui keterkaitan antara pengungkapan GCG, CSR dan kinerja keuangan (ROE). Pengungkapan CSR diukur menggunakan Islamic Social Reporting Index (ISR), sedangkan pengungkapan GCG melalui self assessment atas implementasi GCG bank umum syariah. Sampel yang digunakan adalah perusahaan bank syariah yang terdaftar di Jakarta Islamic Index yang mengikuti aktif diperdagangkan mulai tahun 2012-2016, terdapat informasi pengungkapan CSR pada tahun pengamatan, menerbitkan laporan keuangan tahunan (annual report) secara lengkap tahun 2012-2016 dan memiliki data lengkap terkait dengan variabel yang digunakan. Jumlah sampel dalam perusahaan ini sebanyak 55 sampel. Hasil penelitian menunjukkan 1) Good Corporate 
Governance berpengaruh positif namun tidak signifikan terhadap jumlah Return on Equity (ROE); 2) Corporate Social Responsibility berpengaruh positif tapi tidak signifikan terhadap Return on Equity (ROE); 3) Good Corporate Governance dan Corporate Social Responsibility secara simultan mempunyai pengaruh yang positif namun tidak signifikan terhadap variabel dependen Return on Equity (ROE).

\section{KESIMPULAN MATERI:}

1. Corporate Social Responsibility (CSR) mempunyai pengertian yang mencakup hal-hal berikut: Pelaksanaan CSR untuk meningkatkan kesejahteraan masyarakat secara berkelanjutan, sasaran CSR adalah stakeholders yang terdiri dari stakeholders internal dan eksternal perusahaan, Bidang kerja CSR meliputi manusia dan lingkungannya

2. Good Corporate Governance (GCG) adalah seperangkat sistem yang mengatur dan mengendalikan perusahaan untuk menciptakan nilai tambah (value added) bagi para pemangku kepentingan.

3. Prinsip-prinsip GCG adalah transparancy (keterbukaan), accountability (akuntabilitas), reponsibility (pertanggungjawaban), independency (kemandirian), fairness (kesetaraan, kewajaran) 
4. Salah satu bentuk implementasi dari konsep Good Corporate Governance (GCG), adalah prinsip responsibility yang harus dapat diterapkan dalam operasional perusahaan. Dengan menerapkan prinsip tersebut, perusahaan dianggap sebagai perusahaan yang sehat.

5. Kebijakan Pemerintah terkait kewajiban perusahaan melaksanakan CSR adalah keluarnya UU No 40 Tahun 2007 dan ISO 26000

6. Manfaat pelaksanaan Corporate Social Responsibility meliputi manfaat internal (publik didalam perusahaan) dan manfaat eksternal (publik di luar perusahaan)

\section{KOMPETENSI DASAR:}

Dari hasil kajian ini, diharapkan mahasiswa mampu memahami pentingnya CSR yang wajib dilaksanakan oleh perusahaan, keterkaitan GCG dengan CSR, kebijakankebijakan Pemerintah terkait CSR dan manfaat CSR bagi perusahaan dan masyarakat.

\section{INDIKATOR :}

1. Mahasiswa mampu memahami pengertian Corporate Social Responsibility

2. Mahasiswa mampu memahami Good Corporate Governance 
3. Mahasiswa mampu memahami hubungan antara Corporate Social Responsibility dan Good Corporate Governance

4. Mahasiswa mampu memahami kebijakan Pemerintah terhadap Corporate Social Responsibility

5. Mahasiswa mampu memahami manfaat Corporate Social Responsibility

\section{SOAL:}

1. Jelaskan bagaimana pelaksanaan CSR dari perusahaanperusahaan di Indonesia dan dunia, menurut anda, apakah sudah sesuai dengan pengertian dari CSR yang kita pelajari

2. Jelaskan keterkaitan CSR dengan GCG, berikan contoh (bisa anda ambil dari penelitian terdahulu)

3. Jelaskan kebijakan-kebijakan dari Pemerintah RI dalam pelaksanaan CSR dan bagaimana pendapat anda dengan kewajiban perusahaan untuk melaksanakan CSR

4. Jelaskan manfaat CSR yang dirasakan publik perusahaan, dengan diengkapi contoh konkrit (bisa anda ambil dari penelitian terdahulu atau fakta yang ada di sekitar anda)

\section{DAFTAR PUSTAKA}


Azheri, Busyra. 2012 . Corporate Social Responsibility: Dari Voluntary menjadi Mandatory. Cetakan ke 2. Jakarta: RajaGrafindo Persada

Lako, Andreas. 2011. Dekonstruksi CSR dan Reformasi Paradigma Bisnis dan Akuntansi. Jakarta: Penerbit Erlangga

Kotler, Philip and Lee, Nancy. 2005. Corporate Social Responsibility : Doing The Most Good for Your Company and Your Cause, John Wiley \& Son

Prasiska, Yosa Vega dkk. 2017. CSR dan Citra Perusahaan. Jurnal Bisnis dan Ekonomi (JBE), Maret 2017 (24) (1). Hal 43 - 49. ISSN: 1412-3126 


\section{BAB II}

\section{TRIPLE BOTTOM LINE}

\subsection{Deskripsi Singkat:}

Bab 2 membahas mengenai konsep people, planet dan profit dalam pelaksanaan Corporate Social Responsibility (CSR), piramida CSR, dan penelitianpenelitian pelaksanaan Triple Bottom Line dalam CSR

\subsection{Triple Bottom Line}

Tanggungjawab sosial perusahaan atau CSR merupakan strategi bisnis yang bertujuan untuk menjaga kelangsungan dan keberlanjutan perusahaan. Kondisi ini berdampak pada kegiatan-kegiatan yang dilakukan perusahaan baik untuk stakeholders internal maupun eksternal. Perkembangan ini kemudian memunculkan konsep-konsep baru, dan salah satunya adalah konsep Triple Bottom Line yang dikemukakan oleh John Elkington tahun 1998 melalui bukunya "Cannibals with Forks, the Triple Bottom Line of Twentieth Century Business".

John Elkington mengembangkan konsep Triple Bottom Line yang sebelumnya telah dikembangkan oleh World Commision On Environment and Development (WCED) yaitu economic growth, enviromental protection, dan social equity. Elkington berpandangan bahwa jika 
perusahaan ingin menjaga keberlangsungan hidupnya, maka perusahaan harus memperhatikan 3P, yaitu pijakan yang seimbang pada aspek profit atau keuntungan, people atau masyarakat dan planet atau lingkungan, atau yang lebih dikenal dengan Triple Bottom Line. (Widjaja dan Pratama, 2015: 50)

Profit adalah keuntungan yang diperoleh perusahaan dalam menjalankan kegiatan produksinya. Tetapi dalam Triple Bottom Line, perusahaan bukan hanya bertujuan mencari materi sebanyak-banyaknya sampai harus mengabaikan dampak yang terjadi akibat proses produksi yang dialami lingkungan sekitarnya. Hal ini berarti perusahaan telah berupaya menciptakan fair trade dan ethicall trade yaitu praktek bisnis yang fair dan beretika.

Di sisi lain, perusahaan seharusnya dapat meningkatkan profitabilitasnya karena keuntungan yang didapatkan merupakan dasar bagi perusahaan untuk bertahan dan berkembang. Dengan laba tersebut, perusahaan dapat berbagi keuntungan dengan para pemegang saham, memberikan gaji, tunjangan dan fasilitas yang cukup bagi para karyawannya, melakukan investasi yang menguntungkan untuk masa depan perusahaan, termasuk memenuhi kewajiban pajak kepada Pemerintah dan melakukan kegiatan yang menguntungkan bagi masyarakat sekitar perusahaan.

Profit juga berarti memandang CSR sebagai investasi jangka panjang. Dengan pemikiran tersebut, dalam 
menyusun rencana program kerja dan strategi pelaksanaannya, perusahaan benar-benar memikirkan dampak bagi masa depan dan keberlangsungan hidupnya. Kondisi ini mengharuskan aktivitas-aktivitas CSR yang dilakukan perusahaan berlangsung terus menerus dan berkelanjutan, sehingga masyarakat atau para stakeholders akan mempunyai persepsi dan image yang baik dari kegiatan CSR tersebut.

People atau masyarakat adalah salah satu pihak yang terkena imbas dari aktivitas produksi perusahaan, sehingga perusahaan seharusnya memberikan perhatian lebih kepada masyarakat, khususnya yang ada di sekitar perusahaan, yang mendapatkan dampak secara langsung dari kegiatan peru-sahaan, seperti polusi udara, suara, limbah dan sebagainya. Sebagai perwujudan CSR, perusahaan memberikan sebagian labanya untuk kesejahteraan masyarakat, sehingga kesan yang timbul adalah keuntungan dari kehadiran perusahaan di tengah masyarakat. Bentuk-bentuk CSR bisa berupa materi (uang, fasilitas, sarana dan prasarana) maupun non materi (memberikan kesempatan kepada masyarakat untuk menjadi karyawan perusahaan, memberikan peluang usaha berdagang di sekitar perusahaan, memberikan pelatihan-pelatihan yang dibutuhkan masyarakat, dan lain sebagainya).

Planet atau lingkungan juga menjadi sasaran dari kegiatan CSR perusahaan. Dalam triple bottom line, 
yang dimaksud dengan planet adalah sumber daya alam yang tetap terjaga kelestariannya meskipun perusahaan telah melakukan kegiatan produksinya. Perusahaan harus bertanggungjawab terhadap lingkungan, seperti air, tanah, udara untuk keberlanjutan kehidupan manusia. Faktanya, lingkungan justru menjadi hal pertama yang mengalami kerusakan dan biasanya perusahaan abai dengan kondisi ini. Kita banyak melihat bahkan merasakan sendiri, sungai yang airnya menghitam, tanah yang tidak bisa ditanami, dan udara yang penuh dengan asap dan bau dari proses produksi perusahaan. Dengan konsep Triple Bottom Line dalam CSR, planet atau lingkungan akan lebih diperhatikan dan bahkan menjadi investasi jangka panjang yang menguntungkan perusahaan. Berbagai perwujudan kegiatan untuk lingkungan adalah pengolahan limbah menjadi zero waste, penanaman pohon, pengolahan sampah baik sampah organik (kompos) maupun an organik (daur ulang menjadi barang yang berguna), dan lain sebagainya.

\subsection{Piramida CARROL}

Dalam sub bab ini, sebelum membahas piramida Carol, kita membahas terlebih dahulu tentang stakeholders yang terkena dampak langsung dan tidak langsung dari kegiatan produksi perusahaan. Prinsip Ttriple Bottom Line kemudian menjadi landasan bagi konsep CSR modern, yaitu setiap kegiatan CSR merupakan 
pembangunan yang berkelanjutan dalam semua sektor kehidupan manusia. Konsep ini menggeser tanggungjawab pengelolaan perusahaan yang semula hanya ditujukan kepada stockholders (pemegang saham) bergeser pada stakeholders (pemangku kepentingan), seperti karyawan, pemerintah, konsumen, dan masyarakat luas. Menurut Elkington, tedapat dua jenis stakeholders yaitu traditional stakeholder dan emerging stakeholder.

Pemegang saham dan Pemerintah sebagai pembuat kebijakan dan peraturan adalah pihak-pihak yang termasuk dalam traditional stakeholder. Sedangkan karyawan, konsumen, organisasi akademisi, asosiasi pedagang, masyarakat luas, generasi di masa depan, dan planet bumi termasuk emerging stakeholder. Menurut konsep Triple Bottom Line, keuntungan jangka panjang (sustainability) dapat dicapai ketika perusahaan mempertimbangkan kedua jenis stakeholder yang pada umumnya memiliki konflik kepentingan.

Menurut Achie B. Carrol, secara konseptual, tanggungjawab sosial perusahaan didasari tiga prinsip dasar yang dikenal sebagai Triple Bottom Line. Sedangkan konsep piramida CSR memberi justifikasi teoritis dan logis mengapa sebuah perusahaan perlu melaksanakan CSR untuk masyarakat di sekitarnya. Dalam pandangan Carrol, CSR adalah puncak piramida 
yang terkait erat dengan tanggungjawab filantropis. (Suharto, 2007:104-105)

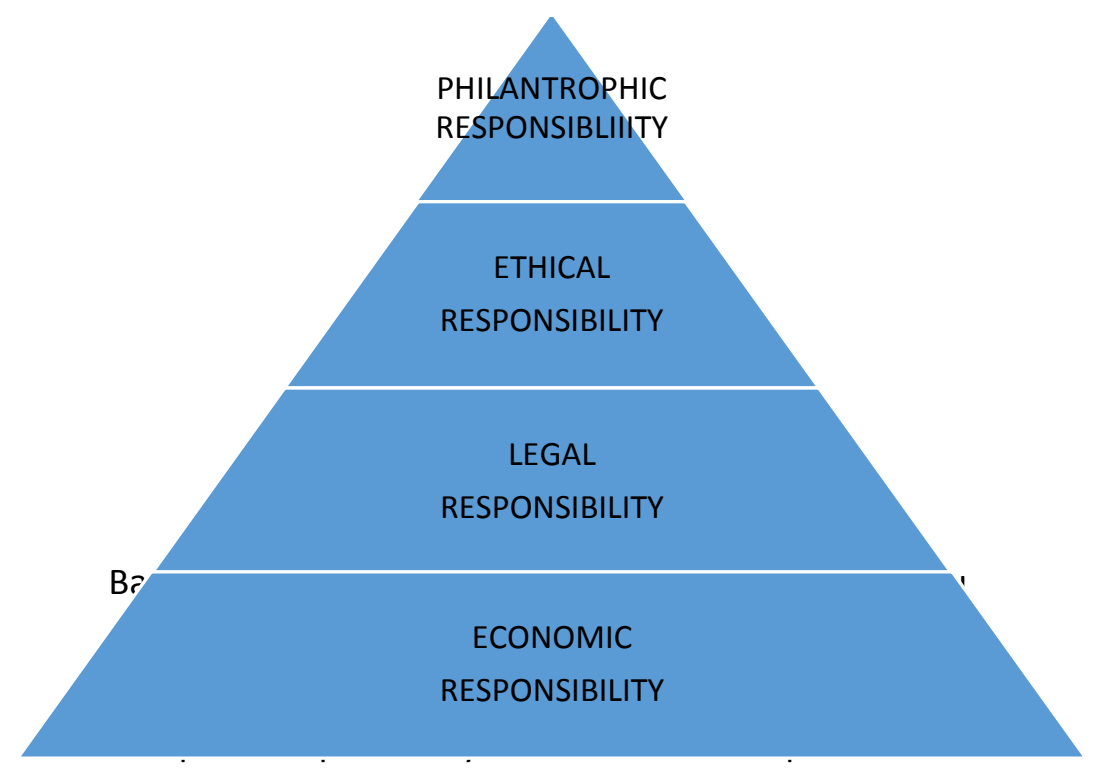

baik secara ekonomi maupun sosial. Carrol memberikan pengertian CSR sebagai "The social responsibility of bussiness encompasses the economic, legal, ethical, and discretionary expectations that society has of organization at a given point of time." 
Dengan demikian Piramida Carrol menjelaskan pandangan masyarakat atas tanggungjawab sosial perusahaan.

\subsubsection{Economic Responsibility}

Economic Responsibility atau tanggungjawab ekonomi harus dilihat sebagai inti dari tanggungjawab, oleh karena itu tanggungjawab ekonomi berada pada posisi paling bawah yang melambangkan landasan. Perolehan keuntungan dan memaksimalkan penerimaan perusahaan adalah tanggung-jawab utama. Dengan kata lain, make a profit adalah kata kuncinya. Perusahaan harus memiliki nilai tambah ekonomi sebagai prasyarat agar perusahaan dapat terus hidup dan berkembang.

Jadi dapat dikatakan bahwa tanggungjawab ekonomi adalah jika perusahaan memperoleh keuntungan sehingga dapat mempertahankan kelangsungan hidupnya dan tanggung-jawab ekonomi dapat diartikan sebagai profit maximization jika perusahaan selalu berusaha meningkatkan kinerja ekonominya. Berdasarkan pemikiran ini, perusahaan yang tidak menghasilkan laba dianggap sebagai perusahaan yang tidak sehat, karena perusahaan didirikan dengan modal yang harus diperoleh kembali dalam jangka waktu tertentu bersama dengan laba, artinya harus balik modal plus laba. 
Faktanya, perusahaan tidak memperoleh keuntungan secara sepihak, tetapi terdapat andil dari masyarakat melalui interaksi antara perusahaan dengan lingkungannya. Bisnis yang baik (good business) bukan perusahaan yang hanya menguntungkan secara ekonomi tetapi juga baik secara moril (ethic).

Tanggungjawab ekonomi yang telah dijalankan dengan baik akan berdampak secara sigifikan kepada investor ataupun kepada stakeholder lainnya, seperti menciptakan lapangan kerja, memproduksi barang dan jasa yang berkualitas dengan tujuan mendapatkan keuntungan, dan mampu membayar pajak kepada pemerintah.

\subsubsection{Legal Responsibility}

Legal responsibility atau tanggungjawab hukum diartikan sebagai obey the law, perusahaan harus taat hukum. Bisnis harus menaati hukum (peraturan) yang berlaku. Perusahaan yang baik adalah perusahaan yang taat pada hukum disertai dengan etika. Dengan demikian, hukum dan etika saling melengkapi, karena dari segi normatif, etika mendahului hukum. Sehingga sering terdengar bahwa perusahaan sudah berlaku etis bila telah menaati hukum. Perusahaan dikatakan sudah memenuhi kewajiban tanggungjawab hukum bila telah bertindak legal dan mematuhi peraturan yang berlaku.

Dalam prakteknya, banyak masalah yang timbul dalam hubungan antara perusahaan dengan hukum. Hukum 
merupakan sudut pandang normatif, karena menetapkan apa yang harus dilakukan dan apa yang tidak boleh dilakukan. Dibandingkan dengan standar dan etika, hukum lebih jelas dan pasti karena hukum ditulis secara hitam diatas putih dan jika dilanggar akan terkena sanksi hukum tertentu.

Hukum dipahami sebagai suatu sistem norma yang mengatur kehidupan bersama dalam masyarakat yang mempunyai sanksi jika tidak dilaksanakan, juga sebagai sarana pemecahan konflik yang rasional karena berdasar fakta-fakta.

\subsubsection{Ethical Responsibility}

Ethical responsibility atau tanggungjawab etis berarti perusahaan memiliki kewajiban untuk menjalankan praktek bisnis yang baik, benar, adil dan fair. Normanorma masyarakat menjadi rujukan bagi perilaku organisasi perusahaan. Termasuk dalam tanggungjawab etis adalah kepekaan korporat dalam menjunjung kearifan dan adat lokal. Pengenalan terhadap kebiasaan, opinion leader, kebudayaan, bahasa daerah, kepercayaan dan tradisi.

Pelaku bisnis disamping mengacu kepada hukum juga harus mendasari perilakunya kepada nilai-nilai etika dan menjadi kebutuhan yang harus diterapkan didalam perusahaan, sehingga perusahaan menyadari bahwa pengelolaan perusahaan patuh pada peraturan tetapi juga membutuhkan kesadaran etika. 


\subsubsection{Philantropic Responsibility}

Philantropic responsibility atau tanggungjawab filantropis adalah tuntutan kepada perusahaan agar memberikan kontribusi yang dapat dirasakan langsung oleh masyarakat, artinya perusahaan harus be a good citizen, menjadi warga negara yang terbaik, bahwa perusahaan memang harus memperoleh laba, mematuhi hukum dan berperilaku baik, benar dan adil, tetapi juga harus berpartisipasi aktif membantu masyarakat secara langsung baik berupa materi maupun non materi. Tujuannya adalah untuk meningkatkan kualitas dan taraf hidup semua pihak, sehingga diharapkan mempersempit jurang si kaya dan si miskin dengan hasil akhir kemandirian masyarakat. Para pemilik dan pegawai memiliki tanggungjawab ganda yaitu kepada perusahaan dan kepada publik.

Dari uraian diatas, piramida tersebut menggambarkan hubungan stakeholder dengan performa CSR, juga komitmen dan pemahaman perusahaan terhadap CSR. Pada tahap Economic Responsibility, perusahaan memandang prioritas utamanya adalah memperoleh keuntungan atau laba dan hanya mengerjakan apa yang dibutuhkan stakeholder. Pada tahap Legal Responsibility, perusahaan hanya mengikuti hukum yang berlaku dalam menjalankan kegiatan usahanya dan program CSR hanya diperuntukkan pada apa yang dibutuhkan stakeholder. Sedangkan Ethical Responsibility mempunyai rujukan yaitu norma-norma 
dan aturan-aturan dalam masyarakat yang tidak tertulis dan memberi perhatian pada harapan stakeholder terhadap perusahaan. Pada tahap ini, perusahaan lebih mengembangkan etika ke arah yang lebih baik karena perusahaan berusaha memenuhi harapan stakeholder. Puncak piramida adalah Philantropic Respon-sibility, pada tahap ini, perusahaan benar-benar memperhatikan keinginan stakeholder, bukan sekedar karena kondisi ekonomi, hukum dan etika yang berlaku di masyarakat. Perusahaan melakukannya karena keinginan untuk berbagi sesuai kebutuhan dan keinginan masyarakat.

Tabel 1

Komponen CSR

\begin{tabular}{|c|c|c|c|}
\hline $\begin{array}{c}\text { ECONOMIC } \\
\text { RESPONSIBILITY }\end{array}$ & $\begin{array}{c}\text { LEGAL } \\
\text { RESPONSIBILITY }\end{array}$ & $\begin{array}{c}\text { ETHICAL } \\
\text { RESPONSIBILITY }\end{array}$ & $\begin{array}{l}\text { PHILANTROPIC } \\
\text { RESPONSIBILITY }\end{array}$ \\
\hline $\begin{array}{l}\text { Maximizing } \\
\text { profit per share }\end{array}$ & $\begin{array}{l}\text { Consistent with } \\
\text { expectations of } \\
\text { government } \\
\text { and law }\end{array}$ & $\begin{array}{l}\text { Consistent with } \\
\text { expectation of } \\
\text { societal mores } \\
\text { ethical norms }\end{array}$ & $\begin{array}{l}\text { Consistent with } \\
\text { the } \\
\text { philantropic } \\
\text { charitable } \\
\text { expectation of } \\
\text { society }\end{array}$ \\
\hline Profitable & $\begin{array}{l}\text { Comply with } \\
\text { regulation }\end{array}$ & $\begin{array}{l}\text { Respect new or } \\
\text { evolving } \\
\text { ethical/ moral } \\
\text { norms adopted } \\
\text { by society }\end{array}$ & $\begin{array}{l}\text { Assist the fine } \\
\text { performing } \\
\text { arts }\end{array}$ \\
\hline $\begin{array}{l}\text { Strong } \\
\text { competitive } \\
\text { position }\end{array}$ & $\begin{array}{l}\text { Law-abiding } \\
\text { corporate } \\
\text { citizen }\end{array}$ & $\begin{array}{l}\text { Prevent ethical } \\
\text { norms from } \\
\text { being }\end{array}$ & $\begin{array}{l}\text { Participate in } \\
\text { voluntary anda } \\
\text { charitable }\end{array}$ \\
\hline
\end{tabular}




\begin{tabular}{|l|l|l|l|}
\hline & & $\begin{array}{l}\text { compromised } \\
\text { in order to } \\
\text { achieve } \\
\text { corporate } \\
\text { goals }\end{array}$ & $\begin{array}{l}\text { activities } \\
\text { within their } \\
\text { local } \\
\text { communities }\end{array}$ \\
\hline Effiency & $\begin{array}{l}\text { Fulfills its legal } \\
\text { obligation }\end{array}$ & $\begin{array}{l}\text { Doing what is } \\
\text { expected } \\
\text { morally or } \\
\text { ethically }\end{array}$ & $\begin{array}{l}\text { Provide } \\
\text { assistance to } \\
\text { private and } \\
\text { public } \\
\text { educational } \\
\text { institution }\end{array}$ \\
\hline $\begin{array}{l}\text { Consistenly } \\
\text { profitable }\end{array}$ & $\begin{array}{l}\text { Meet minimal } \\
\text { legal } \\
\text { requirements }\end{array}$ & $\begin{array}{l}\text { Go beyond } \\
\text { mere } \\
\text { complience } \\
\text { with laws and } \\
\text { regulation }\end{array}$ & $\begin{array}{l}\text { Enhance a } \\
\text { community's } \\
\text { "quality of life" }\end{array}$ \\
\hline
\end{tabular}

Sumber: Carroll, 1991

\subsection{Penelitian-penelitian pelaksanaan Triple Bottom Line} dalam Corporate Social Responsibility

Penelitian terkait dengan pelaksanaan Triple Bottom Line dalam Corporate Social Responsibility (CSR), telah banyak dilakukan oleh para akademisi, dengan tujuan untuk menganalisis kegiatan CSR yang ditujukan kepada People, Planet dan Profit. Beberapa penelitian tersebut akan dibahas disini:

a. Opini Masyarakat terhadap Kegiatan Corporate Social Responsibility PT Pabrik Gula Candi Baru (2015), Panca Wardana. Skripsi tidak diterbitkan.

Penelitian ini bertujuan untuk mendeskripsikan opini masyarakat terhadap kegiatan CSR PT PG Candi 
Baru. Penelitian ini menggunakan metode deskriptif kuantitatif dengan populasi sebanyak 367 KK, peneliti mengambil sampel sebanyak 79 responden. Teknik samplingnya menggunakan teknik Proporsional Sampling dan Random Sampling. Pengumpulan data melalui penelitian kepustakaan, wawancara dan angket. Teknik analisis data yang digunakan menggunakan statistik deskriptif.

Hasil penelitian menyatakan bahwa secara keseluruhan opini masyarakat terhadap kegiatan Corporate Social Responsibility PT PG Candi Baru sudah baik, hal ini ditunjukkan dengan nilai opini yang terendah mencapai $74,5 \%$ dan masuk dalam kategori baik, sedangkan nilai opini yang tertinggi adalah sebesar $90,2 \%$ dan masuk dalam kategori sangat baik, akan tetapi masih ada opini negatif dari masyarakat yang disebabkan oleh beberapa faktor, diantaranya adalah distribusi bantuan yang diberikan tidak merata, bentuk dan jumlah bantuan yang diberikan dianggap tidak sesuai dengan polusi dan kerugian yang diakibatkan oleh aktifitas produksi perusahaan.

Opini masyarakat bisa masuk dalam kategori sangat baik, karena program CSR yang dijalankan PT PG Candi Baru meliputi bidang kerja yang dibutuhkan masyarakat yaitu planet dan people. Planet terkait dengan pendalaman sungai Candi yang telah tercemar limbah-limbah dari perusahaan di sekitar 
desa tersebut. Program people lebih kepada peningkatan kesejahteraan masyarakat yaitu pelatihan dan pendampingan wirausaha, pinjaman modal, perbaikan infrastruktur, pemberian sembako dan santunan, khitanan massal, beasiswa bagi siswa kurang mampu, pengobatan gratis dan mengadakan kejuaraan olah raga.

b. Pengaruh Corporate Social Responsibility dan Brand Image terhadap persepsi masyarakat Buduran (2020), oleh Biqolbi Aqwam, skripsi tidak diterbitkan. Universitas Muhammadiyah Sidoarjo.

Penelitian ini bertujuan untuk membahas pengaruh pelaksanaan Corporate Social Responsibility dan Brand Image PT. Japfa Comfeed terhadap persepsi masyarakat Buduran secara simultan maupun parsial dengan menggunakan teori Triple Bottom Line dan brand image.

Penelitian ini adalah penelitian kuantitatif dengan teknik statistik untuk menguji dua variabel bebas $(X)$ dan variabel terikat $(Y)$. Dimana peneliti meneliti pengaruh pelaksanaan corporate social responsibility $(\mathrm{X} 1)$ dan brand image $(\mathrm{X} 2)$ terhadap persepsi masyarakat Buduran ( $Y$ ). Lokasi penelitian di Desa Wadungasih dan Desa Banjarkemantren Kecamatan Buduran Kabupaten Sidoarjo dengan menggunakan sampel 100 responden. Teknik pengambilan sampel menggunakan teknik random 
sampling. Pengambilan data melalui penyebaran kuisioner kepada responden serta wawancara sebagai bahan pelengkap penelitian. Analisis data menggunakan regresi linier berganda berbasis program SPSS 20.0.

Hasil penelitian menunjukkan terdapat pengaruh antara pelaksanaan corporate social responsibility dan brand image PT. Japfa Comfeed terhadap persepsi masyarakat Buduran yang signifikan dengan nilai $\mathrm{R}$ sebesar 0,864 dan termasuk dalam kategori sangat kuat. Sedangkan kontribusi dari kedua variabel adalah 74,2\%. Hasil uji $F$ menunjukkan terdapat pengaruh secara simultan corporate social responsibility dan brand image terhadap persepsi masyarakat Buduran. Dan uji T menyatakan ada pengaruh secara parsial antara variabel corporate social responsibility, brand image, dan persepsi masyarakat. Jadi kesimpulannya, hipotesis diterima, yaitu terdapat pengaruh Corporate Social Responsibility dan Brand Image terhadap persepsi masyarakat Buduran.

Hasil penelitian lain juga menunjukkan kegiatan CSR dengan merujuk pada Triple Bottom Line yaitu people, planet dan profit, mendapat nilai yang sangat baik dari masyarakat, dengan nilai rata-rata 82,7 . Kegiatan yang berkaitan dengan people meliputi perusahaan merekrut karyawan dari masyarakat sekitar, mengijinkan warga membuka 
usaha/PKL di sekitar perusahaan, memberikan pelatihan ketrampilan, memberi bantuan simpan pinjam, memberikan beasiswa kepada siswa/siswi masyarakat sekitar, dan sumbangan kepada warga kurang mampu.

Planet juga menjadi fokus kegiatan CSR yaitu dengan cara mengolah limbah perusahaan, melakukan penghijauan di desa, dan membantu mengelola sampah masyarakat kedua desa tersebut. Sedangkan profit meliputi kegiatan-kegiatan pemberian diskon produk pada masyarakat sekitra, produk JAPFA Comfeed bermutu dan berkualitas serta perusahaan ini pernah diberitakan media.

c. Implementasi prinsip-prinsip good corporate governance dan Corporate Social Responsibility pada PT Waru Teknikatama, hasil riset Inka Ayu Puspitasari. Skripsi. 2020. Tidak diterbitkan

Tujuan penelitian ini adalah untuk mengetahui dan menganalisis implementasi prinsip-prinsip good corpo-rate governance dan corporate social responsibility pada PT Waru Teknikatama. Penelitian menggunakan pendekatan kualitatif. Infolrman adalah 3 orang yang memahami kondisi PT Waru Teknikatama. Teknik pengumpulan data dengan wawancara, observasi, dan dokumen. Teknik analisis data dengan model interaktif Miles 
dan Huberman. Hasil penelitian menunjukkan bahwa PT Waru Teknikatama telah menerapkan dimensi profit dari triple bottom line melalui efisiensi biaya yang dilakukan dengan menyesuaikan antara realisasi dan anggaran. Biaya CSR PT Waru Teknikatama tidak berasal dari laba, mengingat kemampuan perusahaan sehingga anggaran untuk CSR disesuaikan dengan hal ini. Sedangkan penerapan dimensi people, melalui pembukaan lapangan kerja di workshop yang dapat membantu perekonomian masyarakat setempat, dan perusahaan juga memberikan dana bantuan bagi masyarakat yang membutuhkan serta mengadakan kegiatan untuk para remaja di desa setempat. Implementasi CSR dalam dimensi planet belum dilakukan karena perusahaan ini bergerak dalam jasa kontruksi dengan fokus instalasi atau perakitan, sehingga tidak ada dampak terhadap lingkungan.

\section{KESIMPULAN MATERI:}

1. Profit adalah keuntungan yang diperoleh perusahaan dalam menjalankan kegiatan produksinya. Keuntungan yang didapatkan merupakan dasar bagi perusahaan untuk bertahan dan berkembang. Perusahaan dapat berbagi keuntungan dengan para pemegang saham, memberikan gaji, tunjangan dan fasilitas yang cukup bagi para 
karyawannya, melakukan investasi yang menguntungkan untuk masa depan perusahaan, termasuk memenuhi kewajiban pajak kepada Pemerintah dan melakukan kegiatan yang menguntungkan bagi masyarakat sekitar perusahaan.

2. People atau masyarakat adalah salah satu pihak yang terkena imbas dari aktivitas produksi perusahaan, sehingga perusahaan seharusnya memberikan perhatian lebih kepada masyarakat, khususnya yang ada di sekitar perusahaan, yang mendapatkan dampak secara langsung dari kegiatan perusahaan, seperti polusi udara, suara, limbah dan sebagainya. Bentuk-bentuk CSR bisa berupa materi (uang, fasilitas, sarana dan prasarana) maupun non materi (memberikan kesempatan kepada masyarakat untuk menjadi karyawan perusahaan, memberikan peluang usaha berdagang di sekitar perusahaan, memberikan pelatihan-pelatihan yang dibutuhkan masyarakat, dan lain sebagainya).

3. Planet adalah sumber daya alam yang tetap terjaga kelestariannya meskipun perusahaan telah melakukan kegiatan produksinya. Perusahaan harus bertanggungjawab terhadap lingkungan, seperti air, tanah, udara untuk keberlanjutan kehidupan manusia. Berbagai perwujudan kegiatan untuk lingkungan adalah pengolahan limbah menjadi zero waste, penanaman pohon, pengolahan sampah baik sampah organik (kompos) maupun an organik (daur ulang menjadi barang yang berguna), dan lain sebagainya. 
4. Piramida Carrol menjelaskan pandangan masyarakat atas tanggungjawab sosial perusahaan yang terdiri dari economic responsibility, legal ethical, ethical responsibility, dan philantrophy responsibility

\section{KOMPETENSI :}

Dari hasil kajian ini, diharapkan mahasiswa mampu memahami keseimbangan konsep Triple Bottom Line dalam pelaksanaan CSR dan dapat menjelaskan paradigma Carrol yang merupakan pandangan masyarakat terhadap tanggungjawab sosial perusahaan.

\section{INDIKATOR:}

1. Mahasiswa mampu mengidentifikasi konsep people, planet dan profit dalam pelaksanaan Corporate Social Responsibility

2. Mahasiswa mampu memahami piramida Corporate Social Responsibility

3. Mahasiswa mampu menjelaskan penelitian-penelitian pelaksanaan Triple Bottom Line dalam Corporate Social Responsibility

\section{SOAL :}

1. Jelaskan apa yang dimaksud dengan Triple Bottom Line, terdiri dari apa saja dan jelaskan dengan contoh kegiatan yang berhubungan dengan Triple Bottom Line 
2. Apa yang dimaksud dengan piramida Carrol? Jelaskan tahapan dari piramida CSR tersebut, dilengkapi dengan contoh.

3. Carilah penelitian terdahulu (jurnal atau skripsi) terkait dengan pelaksanaan triple bottom line dalam CSR, jelaskan dengan urutan dibawah ini:

a. Judul penelitian dan nama peneliti

b. Metode penelitian

c. Kesimpulan

\section{DAFTAR PUSTAKA}

Aqwam, Biqolbi. 2020. Pengaruh Corporate Social Responsibility dan Brand Image terhadap persepsi masyarakat Buduran. Skripsi. Universitas Muhammadiyah Sidoarjo.

Carrol, Archie B. 1998. "The Four Faces of Corporate Citizenship,"Business and Societ Review: Journal of The Center for Business Ethics at Bentley College, No. 100-101, pp 1 -7

Suharto, Edi. 2007. Membangun Masyarakat Memberdayakan Rakyat: Kajian Strategis Pembangunan Kesejahteraan Sosial dan Pekerjaan Sosial Edisi ke-2. Bandung: Refika Aditama

Wardhana, Panca dan Ainur Rochmaniah. 2015. Opini Masyarakat Terhadap Kegiatan Corporate Social Responsibility PT Pabrik Gula Candi Baru. Jurnal Kanal 
Vol. 4, No. 1, September 2015, Hal 31 - 44. ISSN: 23026790

Widjaja, Gunawan dan Yeremia Ardi Pratama. 2015. Risiko Hukum \& Bisnis Perusahaan Tanpa CSR Jakarta: Forum Sahabat

\section{BAB III \\ PELAKSANAAN CORPORATE SOCIAL RESPONSIBILITY}

\subsection{Deskripsi Singkat}

Bab 3 membahas mengenai implementasi dan pola model Corporate Social Responsibility, strategi 
penge-lolaan CSR, serta pro dan kontra pelaksanaan CSR

\subsection{Implementasi dan Pola Model Corporate Social Responsibility}

Efektifitas implementasi tanggungjawab sosial atau CSR yang dilaksanakan oleh perusahaan-perusahaan di Indonesia, mempunyai empat model (Saidi,2004: 64 65), yaitu:

a. Keterlibatan langsung

Perusahaan melakukan kegiatan CSR secara langsung kepada masyarakat. Pada model ini, perusahaan menyelenggarakan sendiri kegiatan sosial atau menyerahkan sumbangan ke masyarakat tanpa perantara. Biasanya untuk melaksanakan program ini, perusahaan memberikan tugas kepada salah satu manajer senior seperti public relations officer sebagai bagian dari pekerjaannya atau public affair manager.

b. Melalui yayasan atau organisasi sosial perusahaan Perusahaan mendirikan yayasan sendiri di bawah perusahaan atau grup perusahaannya. Model ini lazim diterapkan oleh perusahaan-perusahaan di negara maju, dan mulai diadopsi oleh perusahaan-perusahaan di Indonesia. Oleh karena itu, perusahaan telah merencanakan sejak awal dengan menyusun anggaran dana yang terdiri dari dana awal, dana rutin, atau dana 
abadi yang dapat digunakan secara teratur oleh yayasan tersebut. Beberapa contoh yayasan CSR yang didirikan oleh perusahaan, yaitu Yayasan Coca Cola Company, Yayasan Dharma Bakti Astra, Yayasan Sahabat Aqua, Yayasan Unilever Indonesia, Yayasan Alianz Peduli.

c. Bermitra dengan pihak lain

Perusahaan menyelenggarakan CSR melalui kerjasama dengan lembaga sosial/organisasi non-pemerintah (NGO/LSM), instansi pemerintah, universitas atau media massa, baik dalam mengelola dana maupun dalam melaksanakan kegiatan sosialnya. Beberapa organisasi sosial/lembaga sosial yang bekerjasama dengan perusahaan dalam melaksanakan CSR antara lain Palang Merah IndonEsia (PMI), Yayasan Kesejahteraan Anak Dompet Dhuafa. Dari instansi pemerintah terdapat Lembaga IImu Pengetahuan Indonesia (LIPI), Badan Nasional Penanganan Bencana (BNPB), Badan Ekonomi Kreatif, Badan Kependudukan Keluarga Berencana Nasional (BKKBN), Kementerian Desa, Pembangunan Daerah Tertinggal dan Transmigrasi RI, Kementerian Kelautan dan Perikanan $\mathrm{RI}$, Kementrian Kesehatan Rl; Univesitas (hampir semua universitas baik negeri maupun swasta telah berkolaborasi dengan perusahaan pelaksana (SR), media massa (DKK Kompas, Kita Peduli Indosiar, SCTV Peduli) 
d. Mendukung atau bergabung dalam suatu konsorsium

Perusahaan turut mendirikan, menjadi anggota atau mendukung suatu lembaga sosial yang didirikan secara bersama-sama dengan perusahaan lain untuk tujuan sosial tertentu. Pihak konsorsium tersebut yang dipercayai oleh perusahaan-perusahaan yang mendukungnya untuuk secara aktif mencari mitra kerjasama dari kalangan lembaga operasional dan kemudian mengembangkan program yang disepakati bersama. Dibandingkan dengan model lainnya, pola ini lebih berorientasi pada pemberian hibah perusahaan yang bersifat "hibah pembangunan". Beberapa contoh konsorsium adalah Konsorsium BUMN, konsorsium ConocoPhilips Corridor, PetroChina Internatioanl Jabung dan PT Transportasi Gas Indonesia (TGI), Konsosium CSR Cilegon.

Efektivitas kegiatan CSR yang tinggi hanya dapat dicapai jika perusahaan tidak berperilaku dermawan, memberikan pendanaan tanpa perencanaan, monitoring dan evaluasi. Sikap ini akan berdampak negatif, masyarakat tergantung pada uang kompensasi, dan selalu berharap setiap waktu tertentu akan mendapatkan dana tersebut tanpa bersusah payah berusaha untuk bekerja. Seharusnya dapat dibangun satu hubungan dalam bentuk mitra kerja untuk mencapai tujuan bersama, yaitu kesejahteraan dalam kemandirian. 
Dibawah ini, tabel yang dapat memperjelas manfaat pelibatan masyarakat setempat oleh perusahaan dalam implementasi program tanggungjawab sosial perusahaan (Siagian, Suriadi, 2010:78-79)

Tabel 2

Manfaat Implementasi CSR Perusahaan

\begin{tabular}{|c|c|}
\hline $\begin{array}{c}\text { Masyarakat setempat pada } \\
\text { perusahaan }\end{array}$ & $\begin{array}{c}\text { Perusahaan pada } \\
\text { masyarakat setempat }\end{array}$ \\
\hline $\begin{array}{l}\text { 1. Reputasi yang lebih baik } \\
\text { 2. Izin untuk beroperasi } \\
\text { secara sosial } \\
\text { 3. Mampu menggunakan } \\
\text { pengetahuan dan tenaga } \\
\text { kerja } \\
\text { 4. Keamanan yang lebih } \\
\text { terjamin } \\
\text { 5. Infrastruktur dan } \\
\text { lingkungan sosial ekonomi } \\
\text { yang lebih baik } \\
\text { 6. Menarik dan menjada } \\
\text { pribadi yang efisien dan } \\
\text { memiliki komitmen yang } \\
\text { tinggi } \\
\text { 7. Menarik pekerja, pemasok, } \\
\text { pemberi pelayanan dan } \\
\text { konsumen setempat yang } \\
\text { berkualitas }\end{array}$ & $\begin{array}{l}\text { 1. Peluang penciptaan } \\
\text { kesempatan kerja, } \\
\text { pengalaman kerja, } \\
\text { dan program latihan } \\
\text { 2. Pembagian } \\
\text { penanaman modal } \\
\text { bagi masyarakat, } \\
\text { pengembangan asas } \\
\text { manfaat } \\
\text { 3. Ketrampilan } \\
\text { perdagangan } \\
\text { 4. Efisiensi teknik dan } \\
\text { pribadi yang terlibat } \\
\text { 5. Keterwakilan ekonomi } \\
\text { sebagai strategi } \\
\text { promosi bagi prakarsa } \\
\text { masyarakat setempat. }\end{array}$ \\
\hline
\end{tabular}


8. Laboratorium kajian pembaruan organisasi

Dalam melaksanakan CSR, setiap perusahaan memiliki karakteristik dan situasi yang unik yang mempengaruhi pandangan mereka terhadap tanggungjawab sosial tidak ada standar atau praktek-praktek tertentu yang dianggap terbaik. Jadi belum ada standar atau praktekpraktek tertentu yang terbaik.

Menurut Prince of Wales Foundation ada lima hal penting yang dapat mempengaruhi pelaksanaan CSR (Untung, 2017:11-12) :

a. Human capital atau pemberdayaan manusia

b. Environments atau lingkungan

c. Good Corporate Governance atau tata kelola perusahaan yang baik

d. Social cohesian atau tidak menimbulkan kecemburuan sosial

e. Economic strenght atau memberdayakan lingkungan menuju kemandirian di bidang ekonomi.

\subsection{Strategi Pengelolaan CSR}

Perusahaan perlu menyusun strategi pengelolaan CSR atau tanggungjawab sosial perusahaan, karena hal ini menentukan sikap dan rencana pelaksanaan CSR di masa sekarang dan masa yang akan datang. Sudarsana 
(2018) mengutip pernyataan Kreitner (2009) bahwa terdapat empat strategi pengelolaan tanggungjawab sosial perusahaan yaitu:

\section{a. Strategi Reaktif}

Kegiatan bisnis yang melakukan strategi reaktif dalam tanggungjawab sosial cenderung menolak atau menghindarkan diri dari tanggungjawab sosial. Dalam banyak kasus, masih ada pihak-pihak yang menentang pelaksanaan CSR walapun sebenarnya telah banyak dari pelaku bisnis dan pemangku kepentingan terkait, yang menyadari dan menyetujui pentingnya perusahaan melakukan kegiatan CSR. Perusahaan yang menganut pendapat tidak terlalu peduli dengan perilaku etis dan umumnya sedapat mungkin akan menyembunyikan tindakannya yang salah.

Ini menunjukkan bahwa para pelaku bisnis khususnya di Indonesia belum banyak yang mendukung program ini. Seperti kasus Lumpur Lapindo Brantas di Sidoarjo, kasus Freeport di Papua, kerusakan hutan dan sebagainya. Semua ini ada hubungannya dengan aktivitas bisnis yang tidak peduli dengan lingkungan sosial dan alam sekitar. Masalah ini tidak hanya terjadi di Indonesia, tetapi juga hampir di semua negara termasuk negaranegara maju.

\section{b. Strategi Defensif}


Strategi defensif dalam tanggungjawab sosial yang dilakukan oleh perusahaan terkait penggunaan pendekatan legal atau jalur hukum untuk menghindarkan diri atau menolak tanggungjawab sosial. Bahkan dalam banyak kasus, perusahaan hanya memenuhi persyaratan hukum secara minimum atas komitmennya terhadap kelompok dan individu dalam lingkungan sosialnya. Ddalam sikap defensif (defensive sttance), organisasi akan melakukan apa saja yang dipersyaratkan oleh peraturan hukum tetapi tidak lebih dari itu. Para manager yang mengambil sikap defensif itu merasa pekerjaan mereka adalah untuk menghasilkan uang bukan malah menghabiskan uang.

Tahun 2016, terjadi penolakan pemberlakuan wajib melakukan CSR oleh para pengusaha. Hal ini terjadi karena DPR akan memasukkan Rancangan UndangUndang (RUU) tentang Tanggung Jawab Sosial Perusahaan atau CSR di daftar program legislasi nasional (Prolegnas) Prioritas tahun 2017 Badan Legislasi DPR. Bahkan Ketua Umum APINDO, Hariyadi Sukamdani mengatakan, pihaknya sangat menentang aturan ini dan mengharapkan DPR membatalkannya, karena akan menjadi beban pajak baru bagi pengusaha. (https://nasional.kontan.co.id/news/pengusaha-siapmati-matian-menolak-ruu-csr, 4 Desember 2016).

Berita diatas menunjukkan bahwa legalitas pajak menjadi tameng perusahaan untuk tidak melaksanakan tanggung jawab sosial nya kepada masyarakat. 


\section{c. Strategi Akomodatif}

Strategi akomodatif merupakan tanggungjawab sosial yang dijalankan perusahaan karena adanya tuntutan dari masyarakat dan lingkungan sekitar.

Perusahaan tetap memberikan bantuannya baik materi maupun non materi tetapi menunggu masukan dan permintaan dari masyarakat. Jadi masyarakat mengajukan permohonan pendanaan secara resmi kepada perusahaan, setelah itu, tanpa birokrasi yang rumit, dana akan cair sesuai permintaan masyarakat.

\section{d. Strategi Proaktif}

Perusahaan memandang bahwa tanggungjawab sosial adalah bagian dari tanggungjawab untuk memuaskan stakeholders. Jika stakeholders terpuaskan, maka citra positif terhadap perusahaan akan terbangun.

Perusahaan melakukan tanggungjawab sosial karena mempunyai pandangan, kepentingan stakeholder perlu diperhatikan disamping kepentingan perusahaan untuk mendapatkan laba yang setinggi-tingginya. Jika kebutuhan stakeholder sudah terpenuhi, akan berdampak pada reputasi perusahaan. Beberapa perusahaan besar melakukan strategi ini untuk mendapatkan image atau citra yang baik dengan berbagai kegiatan yang menjadi kebutuhan masyarakat. Perusahaan Rokok Sampurna konsisten dengan tanggung jawab sosial di bidang pendidikan dengan pemberian beasiswa dan pembangunan fasilitas 
pendidikan. PT Unilever Indonesia tetap pada jalur kesehatan dengan program kesehatan gigi pada anakanak sekolah.

\subsection{Motivasi dan Paradigma CSR}

Ada beberapa motivasi perusahaan dalam melakukan kegiatan corporate social responsibiility atau tanggung jawab sosial perusahaan. Saidi dan Abidin (2004) menjelaskan tahapan motivasi perusahaan dalam melaksanakan CSR, yaitu:

a. Tahap pertama adalah corporate charity, yaitu dorongan amal berdasarkan motivasi keagamaan.

b. Tahap kedua adalah corporate philantrophy, yaitu dorongan kemanusiaan yang biasanya bersumber dari norma dan etika universial untuk menolong sesama dan memperjuangkan pemerataan sosial.

c. Tahap ketiga adalah corporate citizenship, yaitu motivasi kewargaan demi mewujudkan keadilan sosial berdasarkan prinsip keterlibatan sosial.

Tabel 3

Motivasi dan Paradigma CSR

\begin{tabular}{|l|l|l|l|}
\hline Tahapan & Charity & Philantropy & Citizenship \\
\hline Motivasi & Agama, tradisi & Norma etika & Pencerahan \\
& dan adat & dan hukum & diri dan \\
& & universal: & rekonsiliasi \\
& & redistribusi & dengan \\
& & kekayaan & \\
\hline
\end{tabular}




\begin{tabular}{|l|l|l|l|}
\hline & & & $\begin{array}{l}\text { ketertiban } \\
\text { sosial }\end{array}$ \\
\hline Misi & $\begin{array}{l}\text { Mengatasi } \\
\text { masalah } \\
\text { sesaat }\end{array}$ & $\begin{array}{l}\text { Mencari dan } \\
\text { mengatasi akar } \\
\text { masalah }\end{array}$ & $\begin{array}{l}\text { Memberikan } \\
\text { kontribusi } \\
\text { kepada } \\
\text { masyarakat }\end{array}$ \\
\hline Pengelolaan & $\begin{array}{l}\text { Jangka } \\
\text { pendek, } \\
\text { menyelesaikan } \\
\text { masalah } \\
\text { sesaat }\end{array}$ & $\begin{array}{l}\text { Terencana, } \\
\text { terorganisir, } \\
\text { dan } \\
\text { terprogram }\end{array}$ & $\begin{array}{l}\text { Terinternalisasi } \\
\text { dalam } \\
\text { kebijakan } \\
\text { perusahaan }\end{array}$ \\
\hline $\begin{array}{l}\text { Pengorganisa } \\
\text { Sian }\end{array}$ & Kepanitian & $\begin{array}{l}\text { Yayasan/Dana } \\
\text { Abadi: } \\
\text { profeisonalisasi }\end{array}$ & $\begin{array}{l}\text { Keterlibatan } \\
\text { dana dan } \\
\text { sumber daya } \\
\text { lain }\end{array}$ \\
\hline $\begin{array}{l}\text { Penerima } \\
\text { Manfaat }\end{array}$ & Orang miskin & $\begin{array}{l}\text { Masyarakat } \\
\text { luas }\end{array}$ & $\begin{array}{l}\text { Masyarakat } \\
\text { luas dan } \\
\text { perusahaan }\end{array}$ \\
\hline Kontribusi & Hibah sosial & $\begin{array}{l}\text { Hibah } \\
\text { pembangunan }\end{array}$ & $\begin{array}{l}\text { Hibah (sosia } \\
\text { maupun pem } \\
\text { bangunanl dan } \\
\text { ketertiban } \\
\text { sosial }\end{array}$ \\
\hline Inspirasi & Kewajiban & Kewajiban & $\begin{array}{l}\text { Kepentingan } \\
\text { bersama }\end{array}$ \\
\hline
\end{tabular}

Sumber : Saidi dan Abidin (2004) dalam Edi Suharto PhD. Pekerjaan Sosial, CSR, dan Comdev

\subsection{Pro dan Kontra CSR}

CSR atau tanggungjawab sosial perusahaan menjadi tren menarik beberapa tahun terakhir ini, dalam satu survei bahkan disebut ada kenaikan secara signifikan 
kegiatan CSR yang dilakukan perusahaan terhadap masyarakat. Di sisi lain, terdapat perusahaan yang secara terang-terangan maupun sembunyi-sembunyi menolak melakukan CSR, karena dianggap dapat mengurangi pendapatan atau keuntungan perusahaan, CSR adalah beban berat bagi proses produksi. Dibawah ini adalah argumen-argumen kelompok yang pro CSR dan kelompok kontra CSR.

\section{Tabel 4}

Po dan Kontra CSR

\begin{tabular}{|c|c|}
\hline Kelompok Pro CSR & Kelompok Kontra CSR \\
\hline $\begin{array}{l}\text { Kegiatan bisnis seringkali } \\
\text { menim- bulkan masalah, oleh } \\
\text { karena itu sudah semestinya } \\
\text { perusahaan } \\
\text { bertanggungjawab atas apa } \\
\text { yang telah dilakukannya }\end{array}$ & $\begin{array}{l}\text { Perusahaan tidak memiliki ahli } \\
\text { yang mengkhususkan diri dalam } \\
\text { bidang sosial dan } \\
\text { kemasyarakatan, oleh karena } \\
\text { itu sulit bagi perusahaan untuk } \\
\text { ikut bertanggungjawab }\end{array}$ \\
\hline $\begin{array}{l}\text { Perusahaan adalah bagian } \\
\text { dari lingkungan sosial } \\
\text { masyarakat, karena itu } \\
\text { semestinya ikut } \\
\text { bertanggungjawab atas apa } \\
\text { yang terjadi di masyarakatt }\end{array}$ & $\begin{array}{l}\text { Perusahaan yang ikut } \\
\text { berpartisipasi dan } \\
\text { bertanggungjawab dalam } \\
\text { lingkungan masyarakat, justru } \\
\text { akan memiliki kekuatan untuk } \\
\text { mengontrol masyarakat dann } \\
\text { itu indikasi yang kurang baik } \\
\text { secara sosial }\end{array}$ \\
\hline $\begin{array}{l}\text { Perusahaan biasanya memiliki } \\
\text { sumber daya untuk } \\
\text { menyelesaikan masalah di } \\
\text { lingkungan sosial masyarakat }\end{array}$ & $\begin{array}{l}\text { Akan banyak terdapat konflik } \\
\text { kepentingan di masyarakat jika } \\
\text { perusahaan terlibat dalam } \\
\text { aktifitas sosial }\end{array}$ \\
\hline
\end{tabular}




\begin{tabular}{|l|l|}
\hline Perusahaan adalah partner & Tujuan perusahaan bukan untuk \\
dari lingkungan sosial & motif sosial, tetapi untuk \\
masyarakat, sebagaimana & memperoleh profir dan \\
halnya juga pemerintah dan & mencapai tujuan yang \\
masyarakat lain pada & diharapkan oleh para pemilik \\
umumnya & perusahaan \\
\hline
\end{tabular}

\subsection{Penelitian-penelitian Implementasi dan Pola Model CSR}

a. Corporate Social Responsibility di PT. Prudential Life Assurance oleh Ratu Annisa Fairuz, Faachira Faachira, Santoso Tri Raharjo, Risna Resnawaty (2018)

Penelitian ini bertujuan untuk menjelaskan program maupun kegiatan CSR yang telah dilakukan PT. Prudential Life Assurance di Bandung. Jenis metode yang digunakan dalam penelitian ini adalah metode penelitian dekskriptif dengan pendekatan kualitatif. Teknik pengumpulan data yang dilakukan peneliti dalam mengumpulkan data ialah melalui teknik observasi, wawancara, dokumentasi, dan gabungan dari ketiganya.

Kesimpulan dari penelitian ini adalah PT Prudential Life Assurance melakukan kegiatan Corporate Social Responsibility dengan motivasi dan paradigma philantropy dan citizenship. Program CSR PT Prudential Life Assurance adalah Chevening 
Scholarship (beasiswa), Financial Literacy (pengetahuan pengelolaan keuangan bagi kaum perempuan), Kelas Bahasa Inggris di Lapas Anak, Chairman's Challenge (program untuk anak-anak), Cha-Ching Money Smart Kids (edukasi finansial dasar bagi anak-anak), Aksi Bersih (program pencegahan dan penanganan bencana). Semua kegiatan CSR perusahaan ini dilakukan di Jakarta, sebagai lokasi kantor pusat.

b. Pelaksanaan Corporate Social Responsibility (CSR) Bidang Pendidikan PT. Hino Motors Sales Indonesia (PT. HMSI) oleh Dwi Triyanto (2013)

Penelitian ini bertujuan untuk mendeskripsikan pelaksanaan program CSR dalam bidang pendidikan secara aktual yang dilaksanakan oleh PT. Hino Motors Sales Indonesia terhadap keseluruhan stakeholder yang terkait sebagai bentuk tanggung jawab sosialnya. Penelitian mengambil studi kasus di PT. Hino Motors Sales Indonesia (PT. HMSI), melalui pendekatan kualitatif, dengan teknik pengumpulan data wawancara mendalam (in depth interview), dokumentasi dan observasi dan kajian dokumen. Teknik analisis data menggunakan Model Interaktif Miles and Huberman, meliputi reduksi data, penyajian data, dan penarikan kesimpulan. Hasil penelitian menunjukkan bahwa pelaksanaan program CSR PT. HMSI di bidang pendidikan dapat 
dikategorikan ke dalam corporate social marketing dan corporate philanthropy dengan model keterlibatan langsung perusahaan dan bermitra dengan instansi lain. CSR PT. HMSI dalam bidang pendidikan masih berada pada tahap pelaksanaan program dan pada tingkat partisipasi. Faktor-faktor yang mempengaruhi atau mendasari pelaksanaan CSR PT. HMSI adalah karena kesadaran perusahaan akan tanggung jawab terhadap kesinambungan lingkungan dan pengembangan masyarakat dan adanya ketaatan terhadap regulasi dari pemerintah

c. Analisis strategi program Corporate Social Responsibility PT Telkomsel dalam meningkatkan reputasi perusahaan (Analisis program mudik bareng Telkomsel 2015), oleh Erlyta Ruchiyati (2016) Penelitian ini bertujuan untuk menganalisis strategi PT Telkomsel dalam penerapan program CSR Mudik Bareng Telkomsel 2015. Hasil penelitian menunjukkan program CSR mudik bareng adalah aktivitas program termasuk jenis corporate philanthropy (kegiatan filantropi perusahaan) dimana perusahaan memberikan sumbangan langsung dalam bentuk derma untuk kalangan masyarakat tertentu. Program ini menggunakan dua strategi Corporate Social Responsibility dalam prakteknya, yaitu strategi timbal balik dan strategi kewarganegaraan. Program Mudik Bareng Telkomsel 2015 ini lebih berkaitan dengan 
memberikan pelayanan kepada para stakeholders yang ingin pulang kampung halaman serta memberikan tawaran layanan secara terbuka di website Telkomsel. Program ini merupakan salah satu program yang membantu Telkomsel dalam meningkatkan reputasi perusahaan yang terbukti dari peningkatan jumlah peserta setiap tahunnya yang mengikuti program ini.

Melalui program ini, Telkomsel berupaya untuk menumbuhkan dan mengembangkan hubungan baik antara perusahaan dengan publiknya sehingga kedua pihak saling memiliki loyalitas satu sama lain.

\section{KESIMPULAN MATERI}

1. Implementasi dan pola model Corporate Social Responsibility yang dilaksanakan perusahaan antara lain : keterlibatan langsung, melalui yayasan atau organisasi sosial perusahaan, bermitra dengan perusahaan lain, mendukung atau bergabung dalam suatu konsorsium

2. Perusahaan dalam melaksanakan Corporate Social Responsibility mempunyai strategi pengelolaan sehingga efektif dan efisien, yaitu reaktif, defensif, akomodatif dan proaktif.

3. Motivasi dan paradigma dari perusahaan dalam melaksanakan program Corporate Social Responsibility adalah charity, philantropy dan citizenship. 
4. Program Corporate Social Responsibility mendapatkan penolakan (kontra) karena dianggap dapat mengurangi pendapatan atau keuntungan perusahaan dan menjadi beban berat bagi proses produksi.

5. Sedangkan pihak yang pro beranggapan bahwa perusahaan adalah bagian dari lingkungan sosial masyarakat, karena itu semestinya ikut bertanggungjawab atas apa yang terjadi di masyarakat.

\section{KOMPETENSI :}

Dari hasil kajian ini, diharapkan mahasiswa mampu memahami implementasi dan pola model Corporate Social Responsibility, strategi pengelolaan CSR, motivasi dan paradigma CSR serta pro dan kontra pelaksanaan CSR

\section{INDIKATOR}

1. Mahasiswa mampu membandingkan implementasi dan pola model Corporate Social Responsibility

2. Mahasiswa mampu membandingkan strategi pengelolaan Corporate Social Responsibility

3. Mahasiswa mampu membandingkan paradigma pelaksanaan Corporate Social Responsibility

4. Mahasiswa mampu menjelaskan pro dan kontra Corporate Social Responsibility 


\section{SOAL:}

1. Jelaskan implementasi dan pola model CSR dari perusahaan yang melaksanakan program tesebut, dilengkapi dengan contoh.

2. Jelaskan strategi pengelolaan Corporate Social Responsibility, anda bisa melengkapi jawaban dengan contoh dari penelitian terdahulu

3. Jelaskan paradigma pelaksanaan Corporate Social Responsibility dari satu penelitian terdahulu yang anda pilih

4. Pelaksanaan CSR oleh perusahaan mendapatkan dukungan dan penolakan. Menurut anda, perlukah perusahaan melaksanakan CSR, mengapa?

\section{DAFTAR PUSTAKA}

Triyanto, Dwi (2013). Pelaksanaan Corporate Social Responsibility (CSR) di Bidang Pendidikan PT. Hino Motors Sales Indonesia (PT. HMSI). Skripsi. Fakultas Teknik. Universitas Negeri Yogyakarta

Fairuz, Ratu Annisa. Faachira Faachira, Santoso Tri Raharjo, Risna Resnawaty. 2018. Corporate Social Responsibility di PT. Prudential Life Assurance. Prosiding Penelitian \& Pengabdian Kepada Masyarakat e ISSN : 2581-1126 p ISSN: 2442-448X Vol 5, No: 3 Hal: 251 - 259 Desember 2018 
Kreitner, Robert. 2009. Principles of Management. Boston, Massachussets: Cengage Learning

Saidi, Zaim dan Hamid Abidin. 2004. Menjadi Bangsa Pemurah: Wacana dan Praktek Kedermawanan Sosial di Indonesia. Jakarta: Piramedia

Siagian,Matias. Agus Suriadi, 2018. Tanggung Jawab Sosial Perusahaan CSR Perspektif Pekerjaan Sosial, Medan: FISIP USU PRESS

Sudarsana. 2018. Tinjauan Teoritis Tentang Implementasi Tanggung Jawab Sosial Perusahaan. Dialektika Masyarakat: Jurnal Sosiologi p (83-103) Vol. 2, No.1, Mei 2018. ISSN: 2615-7500 


\section{BAB IV \\ BIDANG KERJA CORPORATE SOCIAL \\ RESPONSIBILITY}

\subsection{Deskripsi :}

Pada bab ini, membahas mengenai bidang-bidang kerja dari Corporate Social Responsibility yaitu pendidikan, kesehatan, lingkungan dan ekonomi. Juga akan dibahas tentang bentuk-bentuk CSR dan kategori kerja CSR

\subsection{Bidang Kerja Corporate Social Responsibility}

Konsep Corporate Social Responsibility atau tanggungjawab sosial perusahaan memberikan wajah baru bentuk kepedulian perusahaan terhadap masyarakat. Kepedulian ini didasari oleh pemikiran bahwa kegiatan produksi menimbulkan dampak terhadap lingkungan dan sosial ekonomi di sekitar perusahaan, baik itu secara langsung maupun tidak langsung.

Gray et al (2007:102), perusahaan bertanggungjawab secara sosial ketika manajemen memiliki visi atas kinerja operasional dengan mengutamakan laba tetapi juga harus memperhatikan lingkungan yang ada di sekitarnya.

Ruang lingkup tanggungjawab sosial (CSR) antara lain: 
1) Basic Responsibility adalah tanggungjawab yang muncul karena keberadaan perusahaan, seperti kewajiban membayar pajak, mentaati hukum, memenuhi standar pekerjaan, memuaskan pemegang saham

2) Organizational Responsibility adalah tanggungjawab perusahaan untuk memenuhi kepentingan stakeholder (karyawan, konsumen, pemegang saham dan masyarakat)

3) Societal Responsibility adalah tanggungjawab yang menjelaskan tahapan ketika interaksi antara bisnis dan masyarakat sehingga perusahaan dapat tumbuh dan berkembang secara berkesinambungan

Stakeholders perusahaan adalah para pemangku kepentingan, pihak-pihak yang berkepentingan terhadap eksistensi perusahaan, termasuk didalamnya adalah karyawan, pelanggan, konsumen, pemasok, masyarakat, dan lingkungan sekitar, serta pemerintah selaku regulator.

Wheeler dan Sillanpaa (Wijaya dan Pratama 2008:49) menggolongkan stakeholders dalam dua kategori yaitu stakeholders primer dan stakeholders sekunder.

1) Stakeholders primer adalah stakeholders yang memiliki kepentingan langsung dalam sebuah perubahan dan mempunyai pengaruh, sukses tidaknya perusahaan tersebut. Stakeholers ini 
meliputi pemegang saham, investor, karyawan, pelanggan, komunitas lokal, pemasok dan rekanan bisnis.

2) Stakeholders sekunder merupakan pemangku kepentingan yang sangat berpengaruh secara tidak langsung terhadap kegiatan inti perusahaan, terutama berhubungan dengan reputasi perusahaan. Stakeholders ini meliputi pemerintah, institusi sipil, LSM, pers, pesaing usaha, asosiasi pengusaha dan masyarakat umum.

Princes of Wales Foundation (Untung, 2007:9), terdapat lima hal penting yang mempengaruhi implementasi CSR yaitu:

1) Human Capital

Salah satu tujuan CSR adalah memberdayakan masyarakat dengan hasil akhir, masyarakat yang mandiri dalam segala aspek kehidupan.

2) Environments

Lingkungan sekitar yang bebas dari limbah perusahaan, yang berdampak pada masyarakat dan lingkungan alam.

3) Good Corporate Governance

Tata kelola perusahaan yang baik dapat mewujudkan tujuan yang akan dicapai, salah 
satunya dengan perilaku peduli pada masyarakat dan pengalokasian sumber daya perusahaan menurut hak dan kewajiban.

4) Social Cohesian

Pelaksanaan CSR dengan azas keadilan dan pemerataan dan tidak menimbulkan kecemburuan sosial.

5) Economic Strength

Pemberdayaan lingkungan menuju kemandirian masyarakat secara ekonomi.

Bidang-bidang kerja CSR adalah ruang lingkup kegiatan CSR yang menjadi tolak ukur keberhasilan CSR, diantaranya pendidikan, ekonomi, kesehatan, dan lingkungan.

1) Bidang Pendidikan

Salah satu pilar pembangunan bangsa adalah pendidikan. Hal ini menjadi sasaran kegiatan setiap CSR perusahaan. Berbagai program CSR terkait pendidikan telah banyak dilakukan perusahaan, diantaranya

a. Pembangunan sarana dan prasarana: gedung lengkap dengan meja, kursi dan sebagainya

b. Pemberian beasiswa

c. Pelatihan untuk tenaga pengajar 
d. Pemberian perlengkapan sekolah (seragam, tas dan ATK, buku pelajaran, dan sebagainya).

e. Dukungan untuk pengembangan kompetensi dan potensi siswa, mahasiswa dan tenaga pengajar.

f. Kesempatan untuk magang di perusahaan

2) Bidang Ekonomi

Peningkatan taraf hidup masyarakat di bidang ekonomi menjadi perhatian penting bagi setiap pemangku kebijakan Corporate Social Responsibility. Peningkatan pendapatan ekonomi dengan pemberdayaan masyarakat dapat dilakukan dengan berbagai cara:

a. Pelatihan manajemen dan pemasaran pada Kelompok Usaha Bersama (KUB) dan Usaha Mikro Kecil dan Menengah (UMKM)

b. Pelatihan Agrobisnis

c. Pembukaan lapangan kerja

d. Infrastruktur ekonomi dan usaha produktif lainnya (pemberian hibah dan pinjaman lunak)

3) Bidang Kesehatan

Peningkatan kesehatan masyarakat adalah salah satu target yang akan dicapai CSR perusahaan, beberapa kegiatan CSR bidang kesehatan bahkan menjadi program utama CSR perusahaan- 
perusahaan, seperti yang dilakukan PT Unilever dengan program "Lifebuoy berbagi sehat" dan program "edukasi kesehatan gigi dan mulut Pepsodent". Berikut adalah program kesehatan yang umum dilakukan oleh perusahaan adalah:

a. Pembangunan fasilitas kesehatan seperti pembangunan puskesmas, rumah sakit, klinik kesehatan

b. Program kesehatan ibu dan anak

C. Program cek kesehatan dan pengobatan gratis

d. Pemberian asuransi kesehatan bagi warga sekitar perusahaan

e. Pemberian fasilitas kesehatan untuk berobat pada klinik perusahaan

f. Pengadaan air bersih

4) Bidang Lingkungan

Tanggungjawab terhadap perlindungan lingkungan seringkali dianggap berada di ranah publik. Di masa lalu pemerintah sebagai aktor utama dalam perilaku ramah lingkungan, sedangkan pihak swasta adalah biang masalah lingkungan. Tetapi beberapa tahun belakangan, pergerakan partisipasi perusahaan dalam pelestarian lingkungan mulai nyata dilakukan di sekitar perusahaan.

Berbagai program lingkungan adalah sebagai berikut: 
1) Pengelolaan limbah perusahaan

2) Pengelolaan sampah (daur ulang dan bank sampah)

3) Penanaman pohon (reboisasi)

4) Program bersih-bersih sungai

5) Program edukasi lingkungan pada masyarakat

\subsection{Bentuk-bentuk CSR}

Kotler dan Lee (2005) menyebutkan Corporate Social Inisiative sebagai aktivitas utama yyang dilakukan oleh perusahaan untuk mendukung isu sosial dan untuk memenuhi komitmen terhadap Corporate Social Responsibility.

Berkaitan dengan hal tersebut, terdapat 6 bentuk CSR yang bisa dilakukan oleh perusahaan, yaitu:

a. Cause Promotion (Promosi berhubungan dengan kegiatan sosial), meningkatkan pemahaman dan kepedulian pada masalah kemasyarakatan, antara lain dengan kegiatan sebagai berikut:

1) Perusahaan menyiapkan anggaran atau sumbangan lainnya atau mengadakan suatu kegiatan dengan tujuan meningkatkan pemahaman dan kepedulian masyarakat terhadap masalah kemasyarakatan. 
2) Perusahaan mengadakan kegiatan pengumpulan dana dengan peran serta masyarakat atau menerima sukarelawan untuk aktivitas khusus.

Misal: promosi produk Body Shop, yang menolak menggunakan "animal testing", mengajak menjaga lingkungan hidup dan kelestarian alam

Konsentrasi utama Cause Promotion adalah komunikasi yang dilakukan dengan persuasif, antara lain:

1) Memberikan laporan berupa data statistik serta kondisi nyata suatu problem di masyarakat, dengan maksud menciptakan pemahaman dan kepedulian masyarakat. (misal: jumlah wanita yang menderita osteoporosis lebih tinggi dari pria)

2) Memotivasi masyarakat untuk mendapatkan informasi yang lebih lengkap mengenai suatu problem dengan mengakses website tertentu.

3) Memotivasi masyarakat untuk meluangkan waktu menolong orang lain yang memerlukan pertolongan

4) Memotivasi masyarakat untuk mendermakan uangnya melalui program sosial perusahaan (misal: pundi amal) 
5) Memotivasi masyarakat untuk menyumbang segala sesuatu yang bersifat non material (misal: buku bekas, baju bekas, dll)

Keuntungan yang bisa diperoleh dari kegiatan ini adalah:

1) Memperkuat posisi merk perusahaan

2) Menciptakan loyalitas pelanggan

3) Memberikan peluang kepada karyawan untuk terlibat dalam suatu kegiatan sosial yang menjadi kepedulian mereka.

4) Menciptakan kerja sama dengan pihak lain (misal ; media massa).

5) Memperkuat citra baik perusahaan.

b. Cause -Related Marketing (Pemasaran yang berhubungan dengan kegiatan sosial): memberikan sumbangan untuk menyelesaikan permasalahan melalui pemasaran produk

Perusahaan menyumbangkan sekian prosentase hasil penjualan untuk aktivitas sosial khusus, dengan model ini, pelanggan dapat berperan serta melalui produk yang dibeli. Beberapa aktivitas yang bisa dilakukan perusahaan, antara lain:

1) Perusahaan mendonasikan sejumlah uang tertentu untuk setiap produk yang terjual. (misal 
; Lifebuoy menyumbangkan Rp. 100,- dari setiap batang sabun yang terjual untuk proyek kebersihan)

2) Perusahaan mendonasikan sejumlah uang tertentu untuk setiap aplikasi atau rekening yang dibuka.

3) Membantu menyelesaikan masalah dengan memberikan dana bantuan dari prosentase tertentu dari setiap produk yang terjual atau transaksi untuk kegiatan amal. (misal : Aqua 1 untuk 10, dimana setiap membeli 1 liter Aqua akan digunakan untuk menghasilkan 10 liter air bersih untuk warga di NTT / NTB)

4) Menyisihkan sejumlah prosentase tertentu dari laba bersih perusahaan untuk kegiatan sosial atau untuk amal. (misal: perusahaan BUMN menyisihkan sejumlah laba tertentu yang digunakan untuk kegiatan Program Kemitraan dan Bina Lingkungan)

5) Donasi diambil dari jenis item produk khusus (misal: hanya dari penjualan burger bic Mac)

6) Donasi diambil dari jangka waktu penjualan tertentu (misal: penjualan khusus pada Hari Kemerdekaan).

7) Perusahaan menentukan batas tertentu dari penjualan untuk jumlah dana yang akan diberikan. 
Beberapa manfaat yang bisa diambil perusahaan dari kegiatan ini adalah :

1) Perusahaan dapat menarik konsumen baru.

2) Perusahaan dapat menggalang dana untuk suatu masalah sosial tertentu.

3) Perusahaan dapat mencapai pelanggan dari karakteristik demografi, geografi atau segmen pasar tertentu.

4) Menaikkan penjualan produk.

5) Menciptakan hubungan / relasi yang baik, dan bisa membantu upaya yang dilakukan.

6) Menciptakan brand identity yang positif pada konsumen

c. Corporate Social Marketing (Pemasaran kemasyarakatan perusahaan): mendukung kampanye perubahan perilaku.

Perusahaan memberikan dukungan dalam usaha untuk mengubah tingkah laku yang lebih baik terkait dengan kesehatan, keselamatan, lingkungan atau kesejahteraan masyarakat. Penekananya pada "perubahan tingkah laku" warga. Misal : Program cuci tangan sebelum melakukan sesuatu dari Lifebuoy. Pepsodent dengan program sikat gigi untuk anak-anak sekolah. 
Beberapa manfaat yang bisa diambil dari kegiatan ini adalah :

1) Mendukung posisi merk perusahaan

2) Membentuk preferensi merk (konsumen akan lebih memilih merk produk tersebut.

3) Meningkatkan penjualan.

4) Meningkatkan keuntungan melalui penurunan biaya.

5) Membuat tertarik mitra yang dapat diandalkan serta mempunyai perhatian yang besar untuk merubah tingkah laku warga

6) Mempengaruhi perubahan sosial secara nyata

d. Corporate Philantrophy (Kegiatan filantropi perusahaan): melakukan kegiatan tanggungjawab sosial secara langsung kepada masyarakat. Kegiatan ini adalah bentuk konvensional dari CSR, dimana perusahaan menyerahkan dana langsung dalam bentuk uang untuk kelompok tertentu.

Beberapa hal yang bisa dilakukan antara lain:

1) Pemberian uang tunai (misal : untuk panti asuhan).

2) Pemberian hibah (misal : pembangunan sekolah, kamar mandi umum, beasiswa sekolah, dll).

3) Pendanaan untuk siswa sekola

4) Pembagian hasil produksi perusahaan 
5) Pelayanan gratis atau tidak berbayar

6) Menyiapkan pakar bidang tertentu (misal: layanan hotline konsultasi kesehatan untuk bayi ).

7) Masyarakat diperbolehkan memanfaatkan sarana dan prasarana perusahaan. Seperti musholla dan klinik kesehatan

8) Masyarakat diperbolehkan memakai peralatan yang dimiliki oleh perusahaan.

Keuntungan yang bisa diraih oleh perusahaan adalah :

1) Image perusahaan semakin baik.

2) Masyarakat memberikan kesan baik dan lebih perhatian pada perusahaan

3) Mengokohkan status bisnis perusahaan di masa depan.

4) Problem sosial dalam kelompok lokal dapat diselesaikan

e. Community Volunteering (Pekerja sosial kemasyarakatan), karyawan mendonasikan waktu dan bakat mereka. Dalam hal ini, Perusahaan mendukung dan mendorong karyawan dan stakeholders untuk menjadi relawan dalam kegiatan-kegiatan sosial. 
Bentuk dukungan yang diberikan perusahaan dalam community volunteering antara lain :

1) Perusahaan mensosialisasikan etika organisasi melalui media-media yang ada didalam perusahaan yang akan memotivasi pegawai untuk menjadi sukarelawanbagi masyarakat sekitar

2) Perusahaan mengusulkan program sosial khusus untuk dilakukan pegawai

3) Perusahaan mengelola tim sukarelawan untuk program kemasyarakatan

4) Perusahaan membantu pegawai menemukan program kemasyarakatan melalui riset ke lokasi tertentu

5) Perusahaan memberikan libur dengan tetap menerima gaji untuk pegawai yang menjadi sukarelawan

6) Perusahaan memberikan reward baik materi maupun non materi kepada pegawai

Keuntungan bagi perusahaan dengan melakukan program ini, adalah :

1) Menciptakan relasi yang positif antara perusahaan dengan masyarakat sekitar

2) Memberikan kontribusi pada pencapaian tujuan perusahaan 
3) Menaikkan kepuasan dan mendorong pegawai untuk bekerja lebih baik lagi
4) Memberikan perhatian pada kegiatan lain yang akan dilaksanakan perusahaan
5) Menaikkan reputasi perusahaan
6) Sebagai media publisitas produk dan jasa

f. Socially Responsibility Business Practice (Praktek bisnis yang mempunyai tanggungjawab sosial), luasnya praktek bisnis dan permodalan dalam mendukung masalah kemasyarakatan.

Pengertian dari socially responsibility bussiness practice adalah perusahaan sudah melaksanakan proses produksi yang mendukung upaya memperbaiki kesejahteraan dan perlindungan lingkungan melampaui ketetapan dari kebijakan pemerintah. Artinya kegiatan dari bentuk CSR ini termasuk dalam tingkatan tertinggi karena masyarakat umum yang menjadi sasaran CSR mendapatkan manfaat yang lebih.

Kegiatan dalam point ini meliputi berbagai hal, diantaranya:

1) Membangun fasilitas yang melampui tingkat keselamatan lingkungan dan ketentraman yang ditentukan. 
2) Tidak menerima produk yang terindikasi merugikan kesehatan manusia meskipun produk tersebut sesuai hukum yang berlaku.

3) Pengurangan pemakaian bahan-bahan yang mematikan, misal : bahan kimia

4) Menyeleksi supplier berdasarkan kesiapan mereka mengimplementasikan pengembangan yang berkesinambungan

5) Menentukan perusahaan manufaktur dan bahan packaging yang tidak membahayakan lingkungan dengan membuat aturan-aturan

6) Memberikan informasi yang bermanfaat bagi pelanggan tentang bahan produksi, asal muasalnya, resiko pemakaian serta informasiinformasi yang lain.

7) Mendukung masyarakat yang sejahtera dengan melakukan bermacam kegiatan

Manfaat yang bisa didapat dari kegiatan ini adalah:

1) Pengeluaran tidak melebihi anggaran

2) Reputasi perusahaan semakin baik

3) Label produk perusahaan menjadi pilihan pelanggan

4) Mendapatkan citra yang baik dari Pemerintah

5) Karyawan mendapatkan kebahagiaan

\subsection{Kategori CSR}


Uraian tentang bentuk-bentuk tanggungjawab sosial perusahaan atau CSR dan juga jenis-jenis CSR dapat membawa pada kesimpulan bahwa perusahaan yang telah melaksanakan CSR dimasukan dalam empat kategori bawah ini menurut Rahman (2009) dan Fajar (2010) dari CSR Review, yaitu :

a. Kelompok Hitam

Merupakan perusahaan yang tidak melakukan praktek CSR sama sekali, dimana mereka menjalankan bisnis semata-mata untuk kepentingan sendiri, bagaimana mendapatkan hasil semaksimal mungkin dan tidak peduli kepada lingkungan dan masyarakat sekitar serta tanpa mempertimbangkan efek negatif yang ditimbulkan dari aktivitas perusahaan tersebut.

b. Kelompok Merah

Merupakan perusahaan yang mulai melakukan CSR tetapi memandangnya sebagai beban, yaitu komponen biaya yang akan mengurangi keuntungan, karena CSR dianggap tidak memiliki dampak posotif bagi perusahaan. Perusahaan melakukan CSR karena keterpaksaan akibat tekanan dari masyarakat atau pihak lain. Perusahaan selalu menggunakan alasan ekonomis dimana kondisi perusahaan masih dalam tahap perkembangan, sehingga masih fokus untuk mendapat keuntungan yang maksimal.

c. Kelompok Biru 
Merupakan perusahaan yang berpendapat bahwa kegiatan CSR akan memberikan dampak positif terhadap bisnis dan menganggap CSR sebagai investasi jangka panjang, yang akan memberikan dampak bagi perusahaan berupa citra positif dan bagi masyarakat berupa kontribusi dalam pembangunan berkelanjutan. Perusahaan ini telah menetapkanprogram yang tepat sasaran, dengan tujuan yang terukur dan dijalankan secara berkelanjutan.

d. Kelompok Hijau

Merupakan perusahaan yang telah melaksanakan CSR dan menempatkannya sebagai nilai inti dan menganggapnya sebagai suatu keharusan, bahkan kebutuhan. CSR telah menjadi filosofi dari setiap langkah dan keputusan yang diambil oleh perusahaan, yang berkorelasi dengan kepentingan internal maupun eksternal. Perusahaan sangat memperhatikan aspek lingkungan, sosial dan kesejahteraan karyawan serta melaksanakan prinsip transparansi dan akuntabilitas.

\subsection{Penelitian-penelitian Bidang Kerja}

Beberapa contoh penelitian terkait bidang kerja dapat dideskripsikan dibawah ini:

1. Tanggungjawab Sosial Perusahaan (CSR) Studi Efektifitas Program PT. Pertamina SEHATI (Sehat Ibu 
dan Anak Tercinta) oleh Sandi Gumilar, Hadiyanto A. Rachim, Lenny Meilanny (2017)

Penelitian ini bertujuan untuk mendeskripsikan efektifitas Program CSR PT Pertamina yaitu SEHATI (Sehat Ibu dan Anak Tercinta), dengan menggunakan metode deskriptif kualitatif, pengambilan data dengan cara melakukan observasi dan wawancara terstruktur kepada informan. Penelitian mendapatkan kesimpulan bahwa PT Pertamina Gede Bage berhasil melakukan kegiatan CSR melalui program SEHATI (Sehat Ibu dan Anak Tercinta) di Desa Cisantren Kidul Kecamatan Gede Bage Kabupaten Bandung. Desa ini terpilih sebagai lokasi program CSR PT Pertamina karena memiliki masalah anak yang kekurangan gizi. Program yang bertujuan untuk mengurangi anak yang kekurangan gizi dengan metode penyuluhan oleh CSR PT Pertamina (Persero) dan memberikan makanan khusus untuk anak seperti susu, makanan tinggi protein, makanan tinggi serat dan imunisasi, secara efektif mampu menurunkan angka anak kekurangan gisi di desa tersebut.

2. Tanggungjawab Sosial Perusahaan Dalam Peningkatan Kesejahteraan Masyarakat (Corporate Social Responsibility in Public Welfare Enhancement) oleh Ratih Probosiwi (2016), 
Tujuan penelitian adalah untuk mengetahui implementasi CSR pada PT HM Sampoerna Tbk dalam upaya peningkatan kesejahteraan sosial masyarakat di lingkungan perusaha-annya. Metode penelitian dengan deskriptif kualitatif. Penelitian ini merupakan studi kasus yaitu mengeksplorasi pelaksanaan CSR PT HM Sampoerna dengan batasan terperinci yaitu tempat, program kegiatan, peristiwa, dan aktivitas yang ditujukan untuk mempelajari secara intensif latar belakang dan interaksi yang terjadi dalam implementasi program CSR tersebut. Data yang digunakan berupa data sekunder yang diperoleh melalui studi dokumentasi yaitu laporan pelaksanaan program, catatan, surat kabar, berita internet, dan sebagainya. Data kemudian dianalisis dengan metode analisis deskriptif, yaitu dengan cara mendeskripsikan fakta-fakta yang kemudian disusul dengan analisis, tidak sematamata menguraikan, melainkan juga memberikan pemahaman dan penjelasan secukupnya

Kesimpulan yang diperoleh adalah PT Sampoerna mengadakan program Sampoerna Untuk Indonesia (SUI). Kegiatan SUI mencakup empat pilar utama, yaitu akses terhadap pendidikan, peluang ekonomi, pemberdayaan perempuan, dan tanggap bencana dan kesiapsiagaan. Sampoerna juga menjalankan Sampoerna Entrepreneurship Training Center (SETC) yang memfasilitasi pelatihan untuk lebih dari 22.000 
peserta dan menciptakan kurang lebih 3.300 usaha kecil dan menengah di Indonesia sejak tahun 2007.

Dalam bidang pendidikan, Sampoerna memberikan beasiswa bagi anak karyawan dan dukungan program pendidikan di daerah pemasok tembakau dan cengkeh Sampoerna, mulai dari peningkatan kapasitas guru, hingga akses pendidikan tinggi bagi para siswa. Perhatian tinggi juga diberikan kepada Praktik Pertanian yang Baik (Good Agricultural Practices -GAP) dan Praktik Tenaga Kerja Pertanian (Agricultural Labor Practices -ALP).

Dalam bidang ekonomi, Sampoerna mendirikan Pusat Pelatihan Kewirausahaan Sampoerna (PPKS) tahun 2007 di Pasuruan, Jawa Timur. Selama tujuh tahun terakhir, PPKS telah menerima kunjungan sekitar 55.000 orang, dan mengadakan berbagai pelatihan bagi 22.000 orang.

Sampoerna juga bekerjasama dengan PT Indomarco Pristatama (Indomaret) melalui program Pencegahan Akses Pembelian Rokok oleh Anak-anak (PAPRA) sebagai wujud peran aktif kedua perusahaan dalam menyikapi kekhawatiran atas tingginya angka perokok anak di Indonesia. Tujuannya, untuk meningkatkan kesadaran masyarakat akan pelarangan pembelian produk tembakau oleh anak-anak di bawah 18 tahun, sesuai dengan Peraturan Pemerintah No. 109 tahun 2012 (PP No.109/2012), tentang Pengamanan Bahan yang 
Mengandung Zat Adiktif Berupa Produk Tembakau bagi Kesehatan (Pasal 25 ayat b dan c)

c. Implementasi Corporate Social Responsibility pada perusahaan PT. Anglo Eastern Plantations oleh: Khairunnisak Afrini Sirait (2018), skripsi tidak diterbitkan. Fakultas Ekonomi dan Bisnis Islam Universitas Islam Negeri Sumatera Utara, Medan

Tujuan dari penelitian ini adalah untuk mengetahui implementasi Corporate Social Responsibility (CSR) yang dilakukan oleh PT. AEP (Anglo Eastern Plantations) serta menjelaskan bagaimana pola alokasi Corporate social responsibility (CSR) PT. AEP (PT. Anglo Eastern Plantations). Pendekatan penelitian menggunakan jenis kualitatif dalam bentuk studi kasus. Informan adalah kepala dan staf divisi Corporate Social Responsibility. Teknik pengumpulan data melalui wawancara, pengamatan dan dokumen. Analisis data dengan melakukan data reduction, data display, dan conclusion drawing/verification. Hasil penelitian menyimpulkan bahwa PT AEP (Anglo Eastern Plantations) telah melakukan program CSR dengan beberapa bentuk kegiatan yaitu: 1) Community Development, yaitu suatu bentuk kepedulian yang berkaitan dengan pelayanan masyarakat (pemberdayaan masyarakat). Bidang kerja dari kegiatan ini adalah pendidikan dan kesehatan; 2) Conservation Program (CP), yaitu suatu kegiatan yang bersifat pembenahan 
lingkungan dan pelestarian alam. Untuk Corservation Program, bidang kerja lebih difokuskan pada pelestarian lingkungan, antara lain penghijauan dan pembersihan lingkungan; 3) Community Empowering (CE), suatu kegiatan yang bersifat skill/ pemberian keahlian (peningkatan potensi diri) dengan harapan keahlian tersebut dapat menjadi dasar kemandirian. Bidang kerja dari Community Emprowering dalam bentuk pengembangan skill atau ketrampilan bagi warga sekitar, sehingga masyarakat tidak lagi tergantung pada pihak lain. Perusahaan juga memberikan bantuan dana untuk usaha kecil menengah

\section{KESIMPULAN MATERI:}

1. Bidang-bidang kerja Corporate Social Responsibility meliputi pendidikan, kesehatan, lingkungan dan ekonomi

2. Terdapat 6 (enam) bentuk Corporate Social Responsibility yaitu Cause Promotion, Cause -Related Marketing, Corporate Social Marketing, Corporate Philantrophy, Community Volunteering, Socially Responsibility Business Practice

3. Kategori pelaksanaan Corporate Social Responsibility adalah kategori kelompok hitam, kelompok merah, kelompok biru dan kelompok hijau 


\section{KOMPETENSI}

3. Mahasiswa mampu mengidentifikasi bidang-bidang kerja Corporate Social Responsibility: pendidikan, kesehatan, lingkungan dan ekonomi

4. Mahasiswa mampu mengidentifikasi bentuk-bentuk Corporate Social Responsibility

5. Mahasiswa mampu mengidentifikasi kategori pelaksanaan Corporate Social Responsibility

\section{SOAL :}

1. Jelaskan mengapa perusahaan harus melakukan Corporate Social Responsibility dengan bidang kerja pendidikan, kesehatan, lingkungan dan ekonomi, apa keuntungan dari perusahaan melakukan CSR bidang-bidang tersebut.

2. Analisa penelitian terdahulu yang berkaitan dengan CSR, jelaskan, kegiatan CSR yang dilakukan perusahaan dalam penelitian tersebut, termasuk dalam bentuk CSR yang mana?

3. Analisa juga, termasuk dalam kategori pelaksanaan CSR yang mana? Mengapa?

\section{DAFTAR PUSTAKA}

Fajar, Mukti .(2010). Tanggung Jawab Sosial Perusahaan di Indonesia. Yogyakarta : Pustaka Pelajar.

Gumilar, Sandi. Hadiyanto A. Rachim, Lenny Meilanny. 2017. Tanggungjawab Sosial Perusahaan (CSR) Studi Efektifitas Program PT. Pertamina SEHATI (Sehat Ibu 
dan Anak Tercinta). Jurnal Penelitian \& PKM, Juli 2017

(4) (2) hal: 129 - 389 ISSN 2442-448x (p), 2581-1126 (e)

Kotler, Philip and Lee, Nancy. 2005. Corporate Social Responsibility : Doing The Most Good for Your Company and Your Cause, John Wiley \& Son

Probosiwi, Ratih. (2016), Tanggungjawab Sosial Perusahaan Dalam Peningkatan Kesejahteraan Masyarakat (Corporate Social Responsibility in Public Welfare Enhancement), SOCIA-Jurnal IImu-IImu Sosial, Vol 13, No 2, 2016, (p-ISSN) 1829-5797, (e-ISSN) 2549-9475, h $30-40$

Rahman, R. 2009. Corporate Social Responsibility : Antara Teori dan Kenyataan. Media Pressindo, Yogyakarta 


\section{BAB V \\ SASARAN KERJA CORPORATE SOCIAL \\ RESPONSIBILITY}

\subsection{Deskripsi}

Bab ini membahas mengenai sasaran kerja CSR yang mencakup karyawan, konsumen, komunitas dan lingkungan

\subsection{Sasaran Kerja Corporate Social Responsibility}

Tanggungjawab sosial perusahaan yang dilakukan para pelaku bisnis adalah untuk meminimalisir kerugian yang dialami para stakeholders yaitu karyawan, konsumen, komunitas, lingkungan alam sekitar, juga para pemegang saham. Berbagai program khusus untuk para stakeholders tersebut adalah sebagai berikut:

1. Tanggungjawab terhadap Karyawan

Pelaksanaan CSR terhadap karyawan atau tenaga kerja sangat diperlukan jika melihat kenyataan bahwa masih banyak demostrasi buruh yang menuntut perbaikan upah dan perlindungan kerja, karena jika hal tersebut diabaikan, akan sangat bertentangan dengan konsep CSR sebagai improving the quality of live of the worksforce and their families yang dikemukakan oleh The World Business Council for Sustainable Development (Fajar, 2010:211). Beberapa bentuk tanggung-jawab karyawan yaitu: 
a. Melakukan proses seleksi dan penempatan pegawai secara transparan dengan mengajak para calon pegawai dari sekitar komunitas untuk berpartisipasi

b. Memberikan posisi jabatan dan balas jasa gaji dan pengupahan, serta promosi jabatan tanpa memandang agama, jenis kelamin, suku bangsa, senioritas dan asal negara.

c. Mematuhi peraturan dan UU ketenagakerjaan yang dikeluarkan oleh Pemerintah

d. Memberikan rasa aman karyawan dalam bekerja dengan mengikutsertakan dalam program asuransi tenaga kerja (pensiun dan kecelakaan kerja), asuransi untuk keluarga, perlindungan terhadap pelecehan seksual

e. Memberikan kesempatan yang sama kepada karyawan baik laki-laki dan perempuan, semua level untuk mengikuti program studi lanjut atau pelatihan-pelatihan yang dapat meningkatkan kompetensi karyawan.

f. Memberikan kesempatan beribadah kepada semua karyawan

Semua kegiatan tersebut diatas dapat dilakukan perusahaan melalui beragam cara : 
a. Perusahaan berusaha menangani setiap keluhan dengan menyediakan konseling (konsultasi) dan menyediakan kotak saran

b. Perusahaan mempunyai jadwal rapat rutin setiap hari, setiap minggu dan setiap bulan.

Bentuk tanggungjawab perusahaan kepada karyawan lebih mengarah pada perhatian terhadap segala kebutuhan karyawan, baik secara fisik maupun non fisik.

2. Tanggungjawab terhadap Konsumen

Konsep CSR memandang bahwa perlindungan dan pelayanan kepada konsumen tidak hanya pada persoalan ada tidaknya pelanggaran hukum yang terjadi terkait produk dan atau jasa. Tetapi lebih dari itu, pelaksanaan CSR dalam perlindungan dan pelayanan konsumen adalah adanya kewajiban moral untuk memberikan yang terbaik bagi konsumen, karena selain mentaati perundangundangan dan hukum yang berlaku, korporasi (perusahaan) juga mempunyai tanggungjawab moral kepada konsumen.

Beberapa hak konsumen dari Consumers Bill of Right 1962, yang mengilhami hak konsumen (Fajar, 2010: 216-217) diantaranya: 
a. Hak atas kenyamanan, keamanan dan keselamatan dalam mengkonsumsi barang dan atau jasa

b. Konsumen memiliki hak untuk mendapatkan informasi tentang spesifikasi produk yang dijual perusahaan, antara lain dengan mencantumkan label yang benar, termasuk ampanye iklan diikuti oleh produksi dan distribusi produk yang sesuai dengan pesan-pesan iklan.

c. Konsumen memiliki hak untuk didengarkan, perusahaan dapat membuka kotak pelanggan melalui kotak pos atau nomor telepon.

d. Konsumen memiliki hak untuk dapat memilih barang yang dibeli.

e. Hak untuk mendapatkan advokasi, perlindungan dan upaya penyelesaian sengketa perlindungan secara patut.

f. Hak untuk mendapatkan pembinaan dan pendidikan konsumen.

g. Hak untuk diperlakukan atau dilayani secara benar, jujur serta tidak diskriminatif.

h. Hak untuk mendapatkan kompensasi, ganti rugi dan atau penggantian apabila barang dan atau jasa yang diterima tidak sesuai dengan perjanjian atau tidak sebagaimana mestinya.

Dengan demikian, bentuk tanggungjawab perusahaan terhadap konsumen adalah: 

a. Menciptakan kode etik
b. Memantau semua keluhan
c. Menfasilitasi umpan balik pelanggan dengan menyediakan kotak saran atau hotline

Cara pemerintah menjamin tanggung jawab sosial kepada pelanggan, adalah:

a. Menerbitkan Peraturan Pemerintah tentang keamanan produk, misal : Produk harus melalui uji Halal dari MUI dan ijin produksi PIRT dari Dinkes

b. Peraturan Pemerintah mengenai periklanan, misal: iklan dilarang menayangkan orang sedang merokok dan melakukan porno aksi.

c. Peraturan Pemerintah mengenai kompetisi industri

3. Tanggungjawab terhadap Komunitas/masyarakat sekitar

Pembangunan masyarakat secara eksplisit dalam CSR menurut definisi dari The World Business Council for Sustainable Development diukur berdasarkan kenaikan taraf hidup dari masyarakat, dengan mengacu pada nilai-nilai keadilan dan kesetaraan atas kesempatan, pilihan, partisipasi, timbal balik dan kebersamaan. 
Budiono (dalam Fajar, 2010:228), dalam pelaksanaannya, CSR pada masyarakat sangat membutuhkan peran 3 pilar ekonomi sebuah negara, yaitu pemerintah, masyarakat dan korporasi (perusahaan). Korporasi bersama-sama dengan pemerintah harus berusaha mengurangi kemiskinan, meningkatkan standar kehidupan, dan secara umum memajukan pembangunan masyarakat.

Terdapat tiga tingkatan kegiatan program CSR dalam usaha memperbaiki kesejahteraan masyarakat (Murdiyanto, 2012: 47-50), yaitu:

a. Kegiatan program CSR yang bersifat charity

Bentuk kegiatan ini mempunyai dampak sesaat, hanya menyelesaikan masalah sesaat. Hampir tidak ada dampak pada peningkatan kesejahteraan masyarakat. Walaupun masih sangat relevan, tetapi untuk kepentingan perusahaan dan masyarakat dalam jangka panjang lebih dibutuhkan pendekatan CSR yang berorientasi pada peningkatan produktifitas dan mendorong kemandirian masyarakat. Contoh kegiatan charity adalah pemberian sembako, uang, dan materi yang cepat habis pada saat itu.

b. Kegiatan program CSR yang membantu usaha kecil secara parsial 
Saat ini, sudah banyak perusahaan yang melakukan kegiatan CSR dengan tujuan untuk peningkatan produktivitas dan mendorong kemandirian masyarakat. Salah satunya adalah membantu usaha kecil, tetapi bentuk kegiatan penguatan tersebut masih parsial, terpisah dari kegiatan bidang pendidikan, ekonomi, kesehatan dan pembangunan infrastruktur. Walaupun lebih baik ternyata pada tingkat masyarakat, kegiatan ini tidak dapat diharapkan berkelanjutan, bahkan cenderung meningkatkan ketergantungan masyarakat pada perusahaan, sehingga efek pada pembentukan citra ataupun usaha untuk menggalang kerjasama dengan masyarakat kurang optimal. Contoh kegiatan ini adalah pemberian hibah atau pinjaman lunak, pelatihanpelatihan manajemen tanpa pendampingan, sehingga tidak dapat diukur tingkat keberhasilan dari program ini.

c. Kegiatan program CSR yang berorientasi membangun daya saing masyarakat

Dalam upaya meningkatkan kepedulian terhadap masyarakat sekitar, berbagai macam kegiatan yang dapat dilakukan oleh perusahaan dengan member-dayakan masyarakat dalam beragam bidang yaitu: 
(1) Pengembangan ekonomi, misalnya kegiatan di bidang pertanian, peternakan, koperasi dan Usaha Kecil Menengah (UKM).

(2) Kesehatan dan gizi masyarakat misalnya penyu-luhan, pengobatan, pemberian gizi bagi balita, program sanitasi masyarakat dan sebagainya.

(3) Pengelolaan lingkungan, misalnya penanganan limbah, pengelolaan sampah rumah tangga, rekla-masi dan penanganan dampak lingkungan lainnya.

(4) Pendidikan, ketrampilan dan pelatihan, misalnya pemberian beasiswa bagi siswa berprestasi dan tidak mampu, magang atau job training, studi banding, peningkatan ketrampilan, pelatihan dan pemberian sarana pendidikan.

(5) Sosial, budaya, agama dan infrastruktur misalnya kegiatan bakti sosial, budaya, dan keagamaan serta perbaikan infrastruktur di wilayah masyarakat setempat.

\subsection{Penelitian-penelitian terkait dengan sasaran kerja CSR}

Terdapat beberapa penelitian yang bisa menjadi contoh pelaksanaan CSR dengan sasaran kerja yang jelas.

a. Pengaruh Program Corporate Social Responsibility (CSR) terhadap Peningkatan Kesejahteraan 
Masyarakat dalam Perspektif Ekonomi Islam, oleh Aisyah Amini (2018)

Tujuan dari penelitian ini ialah untuk mengetahui dan menganalisis pengaruh implementasi program CSR PT. PGE Area Ulubelu terhadap peningkatan kesejahteraan masyarakat. Penelitian ini merupakan penelitian lapangan (field research), data primer diperoleh dari kusioner dan wawancara, sedangkan data sekunder dari dokumentasi. Sampel penelitian berjumlah 90 responden (45 responden desa Pagar Alam dan 45 responden desa Ngarip). Metode pengambilan sampel menggunakan teknik purposive sampling, dan data dianalisis dengan mixed methode, yaitu menggabungkan antara metode kuantitatif dan kualitatif dalam suatu penelitian, dan data diolah dengan analisis regresi linear sederhana, menggunakan software SPSS 22.0 untuk menguji hasil kuisioner yang disebar kepada responden.

Hasil penelitian menunjukkan bahwa program CSR PT. Pertamina Geothermal Energy Area Ulubelu, seperti program CSR bidang ekonomi memberikan pengaruh yang positif terhadap peningkatan kesejahteraan masyarakat. Hal ini dikarenakan program CSR PT. Pertamina Geothermal Energy Area Ulubelu menyangkut pemberian modal, pelatihan, serta pendampingan. Sedang program CSR bidang kesehatan, bidang pendidikan, dan bidang lingkungan juga berhasil dilaksanakan seperti 
penyediaan sarana air bersih, Green School, penyediaan sarana posyandu, program penyediaan dana pelatihan bagi guru SD dan SPM, pelestarian alam dan penanggulangan bencana alam melalui penanaman pohon dapat meningkatkan kesehatan dan pendidikan masyarakat menjadi lebih baik.

b. Pengaruh Corporate Social Responsibility (CSR) terhadap Kepuasan Kerja dan Komitmen Organisasi (Penelitian mengenai Internal CSR pada Karyawan PT Pembangkit Jawa-Bali Unit Pembangkitan Paiton) Nurillahizazi Winda Suprayitno dn Heru Susilo (2017)

Tujuan dari penelitiaan ini adalah untuk menggambarkan dan menjelaskan pengaruh Corporate Soccial Respon-sibility terhadap kepuasaan kerja dan komitmen organisasi. Jenis penelitian nmerupakan explanatory research dnggan pendekatan kuantitatif. Populasi pada penelitian ini adalah seluruh kryawan PT PJB UP Paiton yang berjumlah 226 karyawan. Teknik pengambilan sampel yang digunakan adalah proportional random sampling dengan menggunakan rumus Slovin dan didapat jumlah sampel sebanyak 69 karyawan. Sumber data diperoleh dari data primer dan data sekunder. Penelitian menggunakan analisis jalur (Path Analysis) dengan bantuan software SPSS 22.0. 
Hasil dari penelitian menunjukkan Corporate Social Responsibility berpengaruh signifikan terhadap kepuaasan kerja dengan nilai koefisien sebesar 0,751 . Coorporate Social Responsibility tidak berpengaruh signifikan terhadap kommitmen organisasi dengan nilai koefisien 0,074. Kepuasan Kerja berpengaruh siggnifikan terhadap komitmen organnisasi dengan nilai koefisien 0,424. Kepuasan kerja memediasi Corporate Social Responsibility terhadap komitmen organisasi dengan nilai pengaruh tidak langsng lebih besar daripada pengaruh langsungnya. Kepuasan kerja diperoleh karyawan karena PT PJB UP Paiton memberikan pengawasan mengenai pengunaan APD (Alat Pelindung Diri) dan menciptakan suasana kerja yang kondusif.

c. Analisis pengaruh penerapan corporate social responsibility(diversity \& employee support) terhadap kinerja karyawan (studi kasus PT. Batu Rona Adimulya) oleh Titin Heryani dan Zunaidah (2013)

Penelitian ini mempunyai tujuan untuk menganalisis pengaruh konsep Diversity dan Employee support secara parsial dan simultan terhadap kinerja karyawan PT. Baturona Adimulya dan untuk mengetahui variabel mana yang mempunyai pengaruh dominan terhadap kinerja karyawan PT. Baturona Adimulya. Penelitian ini menggunakan 
metode deskriptif kolerasi, dengan populasi adalah seluruh karyawan yang berada di kantor dan di lokasi pertambangan PT. Baturona Adimulya, sebesar 160 orang, dan sampel sebanyak 114 responden dan teknik sampling yang digunakan adalah propotional stratified random sampling. Metode pengumpulan data melalui kuesioner, observasi, dan dokumentasi dan penelitian dianalisis dengan regresi linier berganda.

Kesimpulan penelitian menunjukkan variabel diversity (X1) tidak berpengaruh signifikan sedangkan employee support mempunyai pengaruh yang signifikan terhadap kinerja karyawan. PT.Baturona Adimulya mempunyai karyawan yang berasal dari berbagai daerah, bermacam suku, gender dan agama. Manajemen perusahaan berusaha memper-lakukan keragaman dengan positif, hal ini dimaksudkan agar karyawan merasa nyaman sehingga perputaran karyawan menjadi lebih rendah. Untuk jenis kelamin, karyawan laki-laki masih mendominasi dibandingkan karyawan wanita dikarenakan tingkat kesulitan pekerjaan dalam perusahaan tersebut membutuhkan tenaga laki-laki. Selanjutnya, variabel employee support (X2) memberikan pengaruh secara parsial terhadap kinerja karyawan. Artinya employee support atau motivasi mempengaruhi karyawan. Motivasi berhubungan dengan pemenuhan kebutuhan 
sosiopsikologis, intelektual, kebutuhan yang menunjang rangsangan materi, kualitas ruangan untuk bekerja. Hasil analsis simultan menunjukkan bahwa diversity dan employee support secara bersama-sama mempunyai pengaruh yang signifikan terhadap kinerja karyawan.

\section{KESIMPULAN MATERI:}

1. Sasaran kerja Corporate Social Responsibility adalah karyawan, komunitas, dan konsumen

2. Tanggungjawab terhadap karyawan adalah dengan melaksana-kan dan mematuhi peraturan dan UU ketenagakerjaan yang dikeluarkan oleh Pemerintah, seperti tidak adanya diskriminasi perempuan dan laki-laki, beribadah, dan memberikan kesem-patan yang sama untuk berkarir.

3. Tanggungjawab kepada konsumen, dengan beberapa program, antara lain: menciptakan kode etik, memantau semua keluhan, menfasilitasi umpan balik pelanggan dengan menyediakan kotak saran atau hotline.

4. Tanggungjawab kepada komunitas mempunyai tiga tingkatan yaitu kegiatan program CSR yang bersifat charity, kegiatan program CSR yang membantu usaha kecil secara parsial, kegiatan program CSR yang berorientasi membangun daya saing masyarakat.

\section{INDIKATOR}


3. Mahasiswa mampu memahami Corporate Social Responsibility terhadap karyawan, konsumen dan komunitas

4. Mahasiswa mampu membandingkan Corporate Social Respon-sibility terhadap karyawan, konsumen dan komunitas

\section{SOAL}

1. Carilah penelitian terdahulu tentang Corporate Social Responsibility terhadap karyawan, konsumen dan komunitas (anda memilih 2 dari 3 sasaran CSR diatas)

2. Analisa dengan menjawab pertanyaan berikut ini:

a. Apa saja program dari CSR terhadap karyawan, konsumen dan komunitas tersebut

b. Menurut anda, apakah program-program yang telah dilakukan mempengaruhi kinerja perusahaan baik sisi produksi maupun citra? Jelaskan

3. Jelaskan (lengkapi dengan contoh) apa yang dimaksud dengan:

a. Kegiatan program CSR yang bersifat charity

b. Kegiatan program CSR yang membantu usaha kecil secara parsial,

c. Kegiatan program CSR yang berorientasi membangun daya saing masyarakat. 


\section{DAFTAR PUSTAKA}

Fajar, Mukti (2010). Tanggung Jawab Sosial Perusahaan di Indonesia. Yogyakarta: Pustaka Pelajar

Murdiyanto, Eko dan Muhamad Kundarto. (2012). Membangun Kemitraan Agribisnis: Inovasi Program Corporate Social Responsibility (CSR). Semarang : Yayasan Bina Karta Lestari

Michael, Ricky. Santoso Tri Raharjo, Risna Resnawaty (2019). Program CSR Yayasan Unilever Indonesia berdasarkan Teori Triple Bottom Line. Focus: Jurnal Pekerjaan Sosial (2) (1) Juli 2019. ISSN: 2620-3367. Hal: 23 - 31

Amini, Aisyah. (2018). Pengaruh Program Corporate Social Responsibility (CSR) terhadap Peningkatan Kesejahteraan Masyarakat dalam Perspektif Ekonomi Islam. Skripsi. Fakultas Ekonomi dan Bisnis Islam. Universitas Islam Negeri Raden Intan Lampung

Suprayitno, Nurillahizazi Winda dan Heru Susilo (2017). Pengaruh Corporate Social Responsibility (CSR) terhadap Kepuasan Kerja dan Komitmen Organisasi (Penelitian mengenai Internal CSR pada Karyawan PT Pembangkit Jawa-Bali Unit Pembangkitan Paiton). Jurnal Administrasi Bisnis (JAB) | (44) (1) Maret 2017. Hal $127-133$ 
105 


\section{BAB VI \\ COMMUNITY DEVELOPMENT}

\subsection{Deskripsi:}

Bab 6 membahas mengenai community development meliputi unsur-unsur, jenis program, peran serta masyarakat serta strategi dan perencanaan community development

\subsection{Definisi dan Pengertian Community Development}

Pengembangan masyarakat lokal adalah proses yang ditujukan untuk menciptakan kemajuan sosial dan ekonomi bagi masyarakat melalui partisipasi aktif serta inisiatif anggota masyarakat itu sendiri. Anggota masyarakat bukan dipandang sebagai sistem yang bermasalah, melainkan sebagai masyarakat yang unik dan memiliki potensi, hanya saja potensi tersebut belum sepenuhya dikembangkan.

Pengembangan masyarakat atau Community Development mempunyai 2 pengertian yaitu community dan development. Community bermakna "tingkat kekerabatan dalam masyarakat" dan development berarti "transformasi menuju perkembangan yang dirancang dan dilakukan secara bertahap." Perubahan yang terjadi berasal dari masyarakat, dengan cara yang natural. Hal ini membuat 
masyarakat lebih invofatif dalam menaikkan taraf hidup dan menjadi lebih mandiri.

Beberapa definisi dan pengertian dari Community Development adalah sebagai berikut:

a. Budimanta

Upaya peningkatan taraf hidup masyarakat yang dilakukan secara terorganisir, terprogram, dan ditujukan untuk memperlebar jalan mencapai kondisi sosial, ekonomi, dan kualitas kehidupan yang lebih baik. (Rahman, 2009:108)

b. Soetomo

Suatu proses yang merupakan usaha masyarakat sendiri yang diintegrasikan dengan otoritas pemerintah guna memperbaiki kondisi sosial ekonomi dan kultural komunitas, kedalam kehidupan nasional dan mendorong kontribusi komunitas yang lebih optimal bagi kemajuan nasional (Soetomo, 2008)

c. United Nation

Suatu proses yang didesain untuk menciptakan kondisi ekonomi dan kemajuan sosial untuk komunitas yang berhubungan dengan partisipasi aktif dan untuk memenuhi kemungkinan kepercayaan atas inisiatif komunitas (Luluhatta, 2017) 


\section{d. Sudjana}

Upaya yang terencana dan sistematis yang dilakukan oleh, untuk dan dalam masyarakat guna meningkatkan kualitas hidup penduduk dalam semua aspek kehidupannya dalam suatu kesatuan wilayah.

Dari penjelasan diatas, dapat ditarik kesimpulan bahwa community development adalah upaya pemberdayaan yang dilakukan oleh perusahaan, pemerintah dan masyarakat lokal dengan tujuan agar masyarakat mampu membuat keputusan, mengambil inisiatif dan mampu berdiri sendiri. Masyarakat menjadi lebih berdaya dan mandiri dalam berbagai aspek kehidupan, baik ekonomi, sosial maupun lingkungan hidup.

Dengan pengertian tersebut, maka tujuan dari program community development adalah sebagai berikut:

a. Menimbulkan kepercayaan pada diri sendiri

b. Menimbulkan rasa bangga, semangat, dan gairah kerja

c. Meningkatkan usaha untuk membangun

d. Meningkatkan kesejahteraan masyarakat

Sanders (Christtenson dan Robinson, 1989: 12) menunjukkan empat tipologi atau cara memahami Community Development. 
a. Community development sebagai proses

Community development adalah siklus yang berkelanjutan, dimana terdapat transisi dari keadaan satu ke keadaan berikutnya, dengan tujuan akhir kemandirian masyarakat, yang berupaya memastikan nasibnya sendiri dan mendapatkan cara mencapainya.

b. Community development sebagai salah satu fokus metode

Community development adalah cara kerja yaitu dengan memanfaatkan dua faktor antara lain, partisipasi masyarakat dan perorganisasian. Teknisnya dengan melakukan bimbingan dan latihan serta bantuan lainnya.

c. Community development sebagai program.

Community development adalah proses dan metode serta teknik-teknik tertentu, yang merupakan bagian dari pembangunan. Penekanannya pada pencapaian tujuan bersama dan pencapaian tujuan bersama dan penyelesaian dari serangkaian kegiatan yang dapat diukur hasilnya secara kuantitas juga dapat dilaporkan atau dipertanggungjawabkan.

d. Community development sebagai gerakan. Community development merupakan kegiatankegiatan yang terorganisasi untuk dilaksanakan 
dalam rangkaian pencapaian tujuan dan harapan masyarakat. Sekaligus merupakan media pelembagaan struktur organisasi. Community development dirancang untuk meningkat-kan kehidupan yang lebih baik bagi masyarakat dan merangsang partisipasi, jika dimungkinkan atas prakarsa sendiri. Namun jika prakarsa itu tdak muncul spontan maka dapat dilakukan berbagai teknik untuk memacu tanggapan aktif dan pasif terhadap gerakan itu.

\subsection{Unsur-unsur dalam Community Development}

Dalam mencapai tujuan kegiatan, community development mempunyai unsur-unsur untuk menguatkan program yang dilaksanakan yaitu

a. Program yang dirancang harus mengarah kepada kebutuhan-kebutuhan menyeluruh (total needs) dari masyarakat yang akan menjadi sasaran program (Holistik).

b. Program dapat mendorong swadaya masyarakat (empowerment).

c. Terdapat bantuan teknis baik instansi negara maupun swasta atau lembaga swadaya masyarakat, yang mencakup sumber daya manusia, infrastruktur, dan keuangan. Dalam hal ini lembaga-lembaga tersebut menjadi mitra kerja. 
d. Menyatukan berbagai keahlian seperti pertanian, peternakan, kesehatan masyarakat, pendidikan, kesejahteraan keluarga, kewanitaan, kepemudaan, dll untuk membantu masyarakat (Efendi, 2009)

\subsection{Tiga Jenis Program Community Development}

Menurut Mezirow (1997), terdapat tiga jenis program dalam usaha pengembangan masyarakat, yaitu:

a. Program integratif

Program ini memerlukan pengembangan melalui koordinasi dinas-dinas teknis, menyediakan bantuan teknis dan finansial secara besar-besaran dan melibatkan pejabat-pejabat tiap tingkatan pemerintah (pusat-desa). Contohnya program dari Kementerian Komunikasi dan Informasi Republik Indonesia tahun 2015, diantaranya adalah Kartini Next Generation Award (KKG Award), Duta Internet Cerdas, Kreatif, dan Produktif (CAKAP), Indonesia ICT Award, Festival TIK untuk Rakyat (FesTik) dan Festival Desa TIK (DesTIKa). Kelima program ini merupakan hasil kerjasama dengan kementrian lainny, seperti Kementrian Desa, Pembangunan Daerah Tertinggal dan Transmigrasi, Kementrian Pendidikan dan Kebudayaan Indonesia.

b. Program adaptif

Fungsi pengembangan masyarakat cukup ditugaskan pada salah satu kementerian. Misalnya adalah 
program ABAT (Aku Bangga Aku Tahu) yang dibuat oleh kementerian kesehatan untuk mengatasi permasalahan HIV/AIDS yang makin banyak terjadi pada remaja.

c. Program proyek

Dalam bentuk usaha-usaha terbatas pada wilayah tertentu dan program disesuaikan khusus pada daerah yang bersangkutan. Misalnya: Kabupaten Banjarnegara merupakan salah satu daerah endemis malaria, maka dalam rangka mencegah semakin meluasnya endemis dan mengurangi penderita malaria pemerintah atau dinas kesehatan setempat membuat sebuah program pemberantasan malaria khusus untuk wilayah endemis malaria di Banjarnegara

\subsection{Community Development dan Partisipasi Masyarakat}

Partisipasi adalah keikutsertaan masyarakat dari mulai identifikasi masalah, cara mengatasi, dan langkah yang harus dilakukan dalam menyelesaikan masalahnya sendiri. Keith Davis memberikan pengertian partisipasi, yaitu keterlibatan secara moral untuk berkontribusi dalam upaya mencapai tujuan bersama didalam suatu kelompok, didalamnya terdapat motivasi dan tanggungjawab untuk menyelesaikan secara bersamasama suatu masalah. 
Menurut Sumarto (2009), Partisipasi adalah keterlibatan anggota masyarakat dalam pengambilan keputusan untuk menyelesaikan masalah pembangunan di lingkungannya dan juga berhubungan dengan penggunaan sumber daya, baik sumberdaya manusia maupun sumber daya alam. Keterlibatan anggota masyarakat dalam program pembangunan dapat berupa perencanaan, pengorganisasia, pelaksanaan, monitoring, dan evaluasi.

Mikkelsen dalam Adenansi dkk (2015), menjelaskan proses peran serta masyarakat dalam community development:

a. Keterlibatan pada identifikasi masalah,

Pada proses awal, masyarakat secara bersama-sama dengan pemegang otoritas kebijakan mengidentifikasi persoalan, peluang, potensi dan hambatan.

b. Proses perencanaan,

Masyarakat berperan secara aktif dalam merumuskan rencana dan strategi berdasar pada hasil identifikasi sebelumnya.

c. Pelaksanaan

Masyarakat melakukan kegiatan dengan sungguhsungguh sesuai dengan rencana yang telah disusun bersama-sama dengan sukarela

d. Monitoring 
Masyarakat aktif melakukan kegiatan pengawasan pada saat proses pelaksanaan program, sehingga dapat diketahui program sesuai dengan perencanaan, target dan tujuan.

e. Evaluasi

Masyarakat turut aktif menilai hasil akhir program yang telah dilakukan, apakah pembangunan memberikan manfaat bagi masyarakat atau justru sebaliknya masyarakat dirugikan dengan program ini

f. Mitigasi,

Masyarakat berperan dalam menilai dan menekan pengaruh negatif sebagai dampak dari program yang sedang dilaksanakan.

\subsection{Strategi dan Perencanaan Community Development}

Terdapat tiga pendekatan untuk perencanaan pengembangan masyarakat (community development approach) yaitu (Nindita dalam Alfitri, 2011:34)

a. Developmet for community

Pencetus kegiatan pengembangan masyarakat adalah perusahaan yang mempunyai status sebagai pendonor, sedangkan kedudukan dari komunitas target adalah sebagai obyek kegiatan pengembangan masyarakat. Efek dari kegiatan ini adalah ketergantungan komunitas terhadap perusahaan untuk mencapai tujuan akhir. 
Karakteristik dari progrram ini adalah berorientasi pada perusahaan atau dikenal dengan inkind.

b. Development with community

Kegiatan dilakukan secara bersama-sama antara perusahaan dan masyarakat, mulai dari perumusan, perencanaan, pelaksanaan, sampai evaluasi program yang dilaksanakan. Perusahaan sebagai agen pembangunan, dan komunitas adalah subyek dan obyek program pengembangan masyarakat. Program ini berorientasi pada hasil dan sumbangan pada proses pembangunan, dan menjadikan komunitas tidak terlalu bergantung pada perusahaan, mereka dididik untuk swadaya. Rentang pelaksanaan program cukup lama dan berkesinambungan. Ciri kegiatan ini adalah bertujuan untuk mencukupi keperluan komunitas, juga tujuan perusahaan.

c. Development of community

Program ini mempunyai ciri khas, bertujuan untuk mencukupi keperluan komunitas. Tujuan akhirnya adalah pembangunan yang berproses. Inisiatif program dari warga komunitas, jadi komunitas melakukan survei keperluan dan kegiatan yang akan dilakukan. Oleh karena itu, komunitas sebagai subyek dan perusahaan berperan sebagai agen pembangunan. Dampak positifnya, komu-nitas menjadi self-reliance, berpartisipasi aktif dan mereka yang memutuskan sukses tidaknya kegiatan 
ini. Dengan karakter seperti ini, pelaksanaannya membutuhkan waktu yang lama. Bentuk dari kegiatan biasanya pelatihan dan pendampingan pada komunitas tertentu.

Pengembangan masyarakat (community development) telah menjadi kebijakan yang tepat untuk memberdayakan dan menaikkan taraf hidup masyarakat. Tetapi masyarakat mempunyai kebiasaan dan budaya yang berlainan, yang menjadi kekuatan untuk dapat dikembangkan menjadi modal sosial, oleh karena itu, diperlukan strategi dan pendekatan yang tepat.

Chin dan Benne dalam Nasdian (2006), mengungkapkan strategi pengembangan masyarakat, yaitu rational-empirical, normativereeducative dan power-coorcive.

a. Rational-empirical, kebijakan yang disusun berdasarkan pada hasil penelitian oleh para pakar.

b. Normative-reeducative kebijakan disusun sesuai dengan budaya, sistem nilai yang berlaku di masyarakat dan perilaku keseharian mereka

c. Power-coercive, strategi berasal dari kekuasaan, tidak melihat fakta di lapangan dan cenderung lebih dipaksakan kepada komunitas. 
Dari uraian diatas dapat disimpulkan bahwa terdapat asumsi-asumsi dasar strategi pengembangan masyarakat yaitu production centered development dan people centered development.

a. Production centered development mempunyai pandangan bahwa masyarakat sebagai sekelompok orang yang berpikir konservatif dan mempunyai pendidikan yang rendah, sehingga untuk meningkatkan taraf hidup komunitas tersebut dibutuhkan orang lain dari luar komunitas. Hal ini menjadikan program ini bersifat top-down, terpusat, dirancang oleh para pakar dan lebih mengedepankan perkembangan ekonomi makro. Di sisi lain, masyarakat menganggap para pakar sebagai pihak yang dilayani oleh masyarakat dan berdampak tertutupnya kondisi sosial yang sebenarnya.

b. People centered development beranggapan bahwa masyarakat (komunitas) dengan kompetensi dan sumber daya yang dimiliki, diberdayakan dan dioptimalkan sesuai dengan pengetahuan lokal dan teknologi tepat guna sebagai basis pengembangan masyarakat. Program ini menekankan pada aspek perencanaan secara otonomi berdasarkan kearifan lokal dan peran serta masyarakat yang lebih mengedepankan kebutuhan mikro, 
sehingga masyarakat memperlakukan para pakar sebagai fasilitator yang berdampak bagi kehidupan sosial yang lebih terbuka.

\subsection{Penelitian-penelitian}

Penelitian bertema community development banyak ditemukan di jurnal-jurnal ilmu sosial dan pengabdian masyarakat. Dibawah ini, penulis mengambil 2 contoh penelitian yang bisa dijadikan acuan.

a. Partisipasi masyarakat dalam pembangunan di Kelurahan Sidomulyo Kecamatan Samarinda Ilir Samarinda, oleh Asnar (2016)

Penelitian ini mempunyai tujuan untuk mengetahui, menganalisis, dan mendeskripsikan partisipasi masyarakat dalam pembangunan, serta untuk mengidentifikasi faktor-faktor penghambat dalam pembangunan di Kelurahan Sidomulyo, Kecamatan Samarinda Ilir, Samarinda.

Jenis penelitian deskriptif kualitatif dengan fokus pene-litian adalah partisipasi masyarakat dalam pembangunan, dan teknik analisis data menggunakan model interaktif Miles, Huberman, dan Saldana. Hasil penelitian menunjukkan bahwa masyarakat di Kelurahan Sidomulyo berpartisipasi dalam perencanaan pembangunan dengan cara menyalurkan aspirasi mereka kepada Ketua RT atau tokoh masyarakat setempat, sedangkan dalam 
pelak-sanaan pembangunan, masyarakat berperan pasif karena penggunaan jasa pemborong dalam kegiatan pemba-ngunan dan alasan kesibukan masyarakat masing-masing. Dalam pemanfaatan hasil pembangunan, partisipasi masyarakat masih rendah karena hasil pembangunan yang disediakan tidak digunakan sebagaimana mestinya, serta tidak dijaga dan dirawat dengan baik. Hambatan partisipasi masyarakat adalah rendahnya pemahaman masyarakat akan pentingnya partisipasi mereka dalam mensukseskan pembangunan dan minimnya sosialisasi oleh pihak kelurahan kepada masyarakat terkait informasi pembangunan.

b. Analisis pelaksanaan program community development sebagai bentuk tanggungjawab sosial PT Arara Abadi Distrik Sorek dalam meningkatkan kesejahteraan masyarakat oleh Raendy Herlangga (2017)

Tujuan dari penelitian ini adalah untuk mengetahui dan menganalisis pelaksanaan program community develop-ment sebagai bentuk tanggungjawab sosial PT Arara Abadi distrik Sorek dalam meningkatkan kesejahteraan masyarakat. Penelitian menggunakan metode deskriptif kualitatif. Subjek penelitian ditentukan berdasarkan teknik purposive yang terdiri atas kepala tim pelaksana community development PT Arara Abadi Distrik Sorek, ketua lembaga Mitra Abadi, serta 3 orang anggota lembaga 
Mitra Abadi. Teknik pengumpulan data meliputi observasi, wawancara dan dokumentasi. Teknik analisis data dengan model dan interaktif Miles dan Huberman, dan teknik pemeriksaan keabsahan data meliputi triangulasi dan kecukupan referensi.

Penelitian menghasilkan kesimpulan bahwa pelaksanaan program community development sebagai bentuk tanggungjawab sosial PT Arara Abadi dalam Meningkatkan Kesejahteraan Masyarakat berjalan dengan cukup baik. PT Arara Abadi telah melakukan tanggungjawab sosialnya melalui program kemitraan antara perusahaan dengan masyarakat khususnya masyarakat lokal. Kemitraan tersebut diwujudkan dalam program Desa Makmur Peduli Api (DMPA) untuk membantu peningkatan kesejahteraan masyarakat setempat jangka panjang dengan memberikan sarana produksi kepada masyarakat selama 2 tahun modal tersebut akan dikembalikan kepada perusahaan untuk digulirkan kembali kepada masyarakat lainnya dimana Desa Lubuk Keranji Timur tempat program kemitraan yang dilakukan.

c. Proses community development pada Program Kampung Iklim di Desa Cupang Kecamatan Gempol Kabupaten Cirebon (Studi kasus Program Bank Sampah dalam Program Kampung Iklim) oleh Reza Rinaldy, Soni A. Nulhaqim, Aarie Surya Gutama (2017) 
Penelitian ini bertujuan mendeskripsikan proses com-munity development yang terdiri tahapan engagement, assessment, perencanaan program, pemformulasian rencana aksi, implementasi, evaluasi dan hasil perubahan, dan tahapan terminasi. Proses Community Development yang dilakukan di Desa Cupang melalui program bank sampah dari kegiatan CSR PT. Indocement. Metode penelitian yang digunakan adalah jenis deskriptif dengan pendekatan kualitatif, dan teknik penelitian studi kasus. Teknik pengumpulan data meliputi wawancara mendalam, observasi non partisipasi, studi kepustakaan dan studi dokumentasi. Penelitian ini melibatkan 7 Informan yang terdiri dari, staff divisi CSR Indocement, kelompok pengelolaan sampah, aparat pemerintah Desa Cupang dan masyarakat Desa Cupang yang terlibat langsung dalam program bank sampah. Penentuan informan dilakukan berdasarkan tujuan penelitian untuk menggali lebih dalam mengenai community development pada program bank sampah di Desa cupang.

Hasil dari penelitian ini menunjukan proses community development pada 7 tahapan yang dilakukan hanya ada 5 tahapan yang sudah berjalan sesuai konsep yaitu tahapan engagement, assessment, perencanaan program, Imple-mentasi, dan terminasi. Adapun tahapan evaluasi belum 
dilakukan

secara

menyeluruh

dan berkesinambungan. Temuan lain menunjukkan adanya kendala pada pemasaran produk dan manajemen organisasi terutama terhadap sumber daya manusia (SDM) dalam pelaksanaan kegiatan.

\section{KESIMPULAN MATERI}

1. Community development adalah upaya pemberdayaan yang dilakukan oleh perusahaan, pemerintah dan masyarakat lokal dengan tujuan agar masyarakat mampu membuat keputusan, mengambil inisiatif dan mampu berdiri sendiri. Masyarakat menjadi lebih berdaya dan mandiri dalam berbagai aspek kehidupan, baik ekonomi, sosial maupun lingkungan hidup.

2. Terdapat empat cara memahami community development yaitu community development sebagai proses, metode, program dan gerakan.

3. Jenis-jenis program community development adalah program integratif, adaptif, dan proyek.

4. Peran serta atau partisipasi masyarakat dalam community development meliputi: identifikasi masalah, perencanaan, pelaksanaan, monitoring, evaluasi dan mitigasi.

5. Tiga pendekatan dalam perencanaan community development yaitu development for community, development with community, development of community. 
6. Didalam strategi pengembangan masyarakat terdapat asumsi-asumsi dasar yang menjadi acuan dalam melaksanakan program ini yaitu production centered development dan people centered.

\section{INDIKATOR}

1. Mahasiswa mampu memahami pengertian dari community development.

2. Mahasiswa mampu memahami tujuan dari community developmen.

3. Mahasiswa mampu menjelaskan 4 cara memahami community development.

4. Mahasiswa mampu menjelaskan partisipasi masyarakat dalam community development .

5. Mahasiswa mampu memahami tiga pendekatan dalam perencanaan community development.

6. Mahasiswa mampu memahami asumsi dasar dalam melaksanakan program community development.

\section{SOAL :}

1. Carilah penelitian terdahulu terkait community development, jawablah pertanyaan dibawah ini:

a. Setelah anda membaca, menurut anda, apa yang dimaksud dengan community development

b. Jelaskan, apa perbedaan dari community development dan corporate social responsibility 
2. Titik point dari community development adalah partisipasi masyarakat, bagaimana pendapat anda, perlukah masyarakat berperan serta dalam program community development.

3. Jelaskan tiga pendekatan dalam perencanaan community development! Dari penelitian terdahulu yang anda pilih, pendekatan dari program community developmen memakai pendekatan yang mana?

4. Jelaskan asumsi-asumsi dasar dalam melaksanakan program community development. Berikan contoh dengan mencari penelitian tentang community development.

\section{DAFTAR PUSTAKA}

Adenansi, Dhio. Moch. Zainuddin, \& Binahayati Rusyidi.2015. Partisipasi masyarakat dalam program pemberdayaan masyarakat PNPM Mandiri. Prosiding KS: Riset \& PKM (2) (3) tahun 2015 hal: 347 - 353 ISSN: 2442-4480

Asnar. 2016. Partisipasi masyarakat dalam pembangunan di Kelurahan Sidomulyo Kecamatan Samarinda Ilir Samarinda. Gulawentah: Jurnal Studi Sosial (1) (2) Desember 2016, hal. 121-131

Efendi, Ferry dan Makhfudli. 2009. Keperawatan Kesehatan Komunitas: Teori dan Praktik dalam Keperawatan. Jakarta: Salemba Medika.

Herlangga, Raendy. 2017. Analisis pelaksanaan program Community Development sebagai bentuk 
tanggungjawab sosial PT Arara Abadi Distrik Sorek dalam meningkatkan kesejahteraan masyarakat Jom FISIP Volume 4 NO. 2 Oktober

Rahman, Reza. 2009. Corporate Social Responsibility: Antara Teori dan Kenyataan. Yogyakarta: Media Pressindo.

Soetomo, Pembangunan Masyarakat , (Yogyakarta : Pustaka Pelajar, 2008), h. 79

Sumarto, H Sj. 2009. Inovasi, Partisipasi, dan good Governance. Jakarta: Yayasan Obor Indonesia.

Triyono, Agus. 2014. Pemberdayaan Masyarakat Melalui Community Development Program Posdaya

(Pos Pemberdayaan Keluarga) Pt. Holcim Indonesia Tbk Pabrik Cilacap. KomuniTi, Vol. VI, No. 2 September 2014, h $111-121$

https://kominfo.go.id/content/detail/4544/menkominfoluncurkan-lima-program-pemberdayaan-masyarakatbidang-tik/0/sorotan media 


\section{DAFTAR PUSTAKA}

\section{Buku}

Andreas Lako. (2011). Dekonstruksi CSR dan Reformasi

Paradigma Bisnis \& Akuntansi. Jakarta : Penerbit Erlangga.

Azheri, Busyra.2012.Corporate Social Responsibility: Dari Voluntary menjadi Mandatory. Cetakan ke 2. Jakarta: RajaGrafindo Persada

Budimanta, Arif dan Bambang Rudito. 2008. Metode dan Teknik Pengelolaan Community Development, cet. Ke II Jakarta: CSD. hal. 33.

Carrol, Archie B. 1979. A Three-Dimensional Conceptual Model of Corporate Performance, The Academy of Management Review. Vol. 4. Oktober : 497 - 505

Carrol, Archie B. 1998. "The Four Faces of Corporate Citizenship,"Business and Societ Review: Journal of The Center for Business Ethics at Bentley College, No. 100101, pp $1-7$

Edi Suharto, 2007. Pekerja Sosial di Dunia Industri memperkuat tanggung jawab sosial perusahaan, Bandung: Refika Aditama, h. 104-105

Efendi, Ferry dan Makhfudli. 2009. Keperawatan Kesehatan Komunitas: Teori dan Praktik dalam Keperawatan. Jakarta: Salemba Medika

Eko Murdiyanto \& Muhamad Kundarto. 2012. Membangun. Kemitraan Agribisnis : Inovasi Program Corporate Social Responsibility (CSR). Semarang : Yayasan Bina Karta Lestari

Elkington, J. 1997. Cannibals with Forks: The Triple Bottom Line Of $21^{\text {st }}$ Century Business, Capstone, Oxford Hendrik, Budi Untung, 2017. Corporate Social Responsibility, Jakarta: Sinar Grafika. h. 11-12. 
Kartini, Dwi. Prof. Dr. 2009. Corporate Social Responsibility: Transformasi Konsep Sustainability Management dan Implementasi di Indonesia. Bandung: Refika Aditama

Kotler, Philip and Lee, Nancy. 2005. Corporate Social Responsibility : Doing The Most Good for Your Company and Your Cause, John Wiley \& Son

Kreitner, Robert. 2009. Principles of Management. Boston, Massachussets: Cengage Learning

Matias Siagian, Agus Suriadi, 2010. Tanggung Jawab Sosial Perusahaan CSR Perspektif Pekerjaan Sosial, (Medan: FISIP USU PRESS. h. 78-79.

Mukti Fajar. 2010. Tanggung Jawab Sosial Perusahaan di Indonesia. Yogyakarta : Pustaka Pelajar.

Nafisah, Khudrotun. 2017. Konsep Kepedulian Sosial Perusahaan, Peran Perusahaan sebagai Warga Negara, dan Kinerja Sosial Perusahaan. Makalah kuliah CSR dan Modal Sosial Jurusan Sosiologi FISIP Universitas Darul Ulum, 15 Mei 2017. Dapat diunduh di academia.edu

Prahalad, C.K and L. Hart, Stuart. 2001. The Fortune at The Bottom of The Pyramid

Post, James E., and Lawrence, Anne T., anda Weber, James. 2002, Business and Society: Corporate Strategy, Public Policy, Ethics, tenth edition, McGraw Hill

Rahman, R. 2009. Corporate Social Responsibility : Antara Teori dan Kenyataan. Yogyakarta : Media Pressindo

Saidi, Zaim dan Hamid Abidin. 2004. Menjadi Bangsa Pemurah: Wacana dan Praktek Kedermawanan Sosial di Indonesia. Jakarta: Piramedia

Servera, David and Lidia Piqueras. 2019. The Effect of Corporate Social Responsibility on Consumer Loyalty Through Consumer Perceived Value. Journal Economic 
Research-Ekonomska Istrazivanja. Vol 31, 2019. https://www.tandfonline.com/

Solihin, I. 2009. Corporate Social Responsibility: From Charity to Sustainability. Jakarta: Salemba Empat

Soetomo, 2008. Pembangunan Masyarakat, (Yogyakarta : Pustaka Pelajar, h. 79

Suhartono, Tatik Suryani dan Lindiawati. 2019. Corporate Social Responsibility di Indonesia: Konsep dan Praktik Bisnis dan Perbankan. Surabaya: JP Books

Suharto, Edi. 2007. Membangun Masyarakat Memberdayakan

Rakyat: Kajian Strategis Pembangunan Kesejahteraan Sosial dan Pekerjaan Sosial Edisi ke-2. Bandung: Refika Aditama

Sumarto, H Sj. 2009. Inovasi, Partisipasi, dan good Governance. Jakarta: Yayasan Obor Indonesia.

Undang-Undang Perseroan Terbatas Republik Indonesia Tahun 2007

Wahyudi, I. dan Azheri, B. 2008. Corporate Social Responsibility. Malang: Setara Press

Widjaya, Gunawan. Yeremia Ardi Pratama. 2008. Corporate Social Responsibility: The WBCD"s journey 2002. Risiko Hukum \& Bisnis Perusahaan Tanpa CSR, Jakarta: Forum Sahabat, h. 8.

Widjaja, Gunawan dan Yeremia Ardi Pratama. 2015. Risiko Hukum \& Bisnis Perusahaan Tanpa CSR Jakarta: ForumSahabat

World Business Council for Sustainable Development, 2001, The Business Case for Sustainable Development, WBCSD, Geneva 


\section{Jurnal dan Skripsi}

Adenansi, Dhio. Moch. Zainuddin, \& Binahayati Rusyidi.2015. Partisipasi masyarakat dalam program pemberdayaan masyarakat PNPM Mandiri. Prosiding KS: Riset \& PKM (2) (3) tahun 2015 hal: 347 - 353 ISSN: 2442-4480

Amini, Aisyah. 2018. Pengaruh Program Corporate Social Responsibility (CSR) terhadap Peningkatan Kesejahteraan Masyarakat dalam Perspektif Ekonomi Islam. Skripsi. Fakultas Ekonomi dan Bisnis Islam. Universitas Islam Negeri Raden Intan Lampung

Aqwam, Biqolbi. 2020. Pengaruh Corporate Social Responsibility dan Brand Image terhadap persepsi masyarakat Buduran. Skripsi tidak diterbitkan. Universitas Muhammadiyah Sidoarjo

Asnar. 2016. Partisipasi masyarakat dalam pembangunan di Kelurahan Sidomulyo Kecamatan Samarinda Ilir Samarinda. Gulawentah: Jurnal Studi Sosial (1) (2) Desember 2016, hal. 121-131

Dessy, Novia Kartisari. 2017. Pengaruh Corporate Social Responsibility terhadap Citra Perusahaan Multinasional. Jurnal Administrasi Bisnis, Vol. 43, No. 1 Maret 2017. ISSN: 2338-4654

Fairuz, Ratu Annisa. Faachira Faachira. Santoso Tri Raharjo. Risna Resnawaty. 2018. Corporate Social Responsibility di PT. Prudential Life Assurance. Prosiding Penelitian \& Pengabdian Kepada Masyarakat e ISSN : 2581-1126 p ISSN : 2442-448X Vol 5, No: 3 Hal: 251 - 259 Desember 2018

Hardiani. 2016. Pengaruh Corporate Social Responsibility terhadap Brand Image Perusahaan (Studi Pada PT Bank BRI Tbk (Persero) Cabang Makasar. Jurnal Ilmiah 
BONGAYA (Manajemen dan Akuntansi), April 2016 No XIX ISSN: $1907-5480$

Herlangga, Raendy. 2017. Analisis pelaksanaan program Community Development sebagai bentuk tanggungjawab sosial PT Arara Abadi Distrik Sorek dalam meningkatkan kesejahteraan masyarakat Jom FISIP Volume 4 NO. 2 Oktober 2017

Heryani, Titin, dan Zunaidah, 2013. Analisis pengaruh penerapan corporate social responsibility(diversity \& employee support) terhadap kinerja karyawan (studi kasus PT. Batu Rona Adimulya). Jurnal Manajemen dan Bisnis Sriwijaya (11) (2) Juni 2013. hal 149 - 180

Jamaluddin, Suhardi M. Anwar. 2017. Pengaruh CSR PT Vale Indonesia Tbk Terhadap Kesejahteraan Masyarakat Sekitar Kecamatan Nuha. Jurnal Ekonomi Pembangunan STIE Muhammadiyah Polopo. Vol. 3, No. 2. ISSN: 23391510

Javier, Jose Rivera et all. 2019. Effect of Corporate Social Responsibility on Consumer Brand Loyalty. Revista Brasileira de Gestao de Negocios. ISSN: 1806-4892. Vol. 21. No. 3. July/Sept 2019. Sept.23. scielo.br/scielo Michael, Ricky. Santoso Tri Raharjo, Risna Resnawaty (2019). Program CSR Yayasan Unilever Indonesia berdasarkan Teori Triple Bottom Line. Focus: Jurnal Pekerjaan Sosial (2) (1) Juli 2019. ISSN: 2620-3367. Hal: 23 - 31

Puspitasari, Inka Ayu. 2020. Implementasi prinsip-prinsip good corporate governance dan Corporate Social Responsibility pada PT Waru Teknikatama. Skripsi. Tidak diterbitkan

Putu, Ni Yeni Astiti dan Putu Wenny Saitri. 2016. Pengaruh Corporate Social Responsibility Terhadap Kesejahteraan Masyarakat dan Citra Perusahaan. Jurnal Bisnis dan Kewirausahaan, Vol. 12, No. 2 Juli 2016. ISSN: 0216-9843 
Ratih Probosiwi. 2016, Tanggungjawab Sosial Perusahaan Dalam Peningkatan Kesejahteraan Masyarakat (Corporate Social Responsibility in Public Welfare Enhancement), SOCIA-Jurnal IImu-IImu Sosial, Vol 13, No 2, 2016, (p-ISSN) 1829-5797, (e-ISSN) 2549-9475, h 30 40

Rinaldy, Reza, Soni A. Nulhaqim, Aarie Surya Gutama. 2017. Proses community development pada Program Kampung Iklim di Desa Cupang Kecamatan Gempol Kabupaten Cirebon (Studi kasus Program Bank Sampah dalam Program Kampung Iklim). Jurnal Penelitian \& PKM Juli 2017 (4) (2) Hal: 129 - 389 ISSN 2442-448X (p), 2581-1126 (e)

Ruchiyati, Erlyta. 2015. Analisis strategi program Corporate Social Responsibility PT Telkomsel dalam meningkatkan reputasi perusahaan (Analisis program mudik bareng Telkomsel. Makalah Non Seminar. Prodi Ilmu Komunikasi. FISIP Universitas Indonesia

Sandi Gumilar, Hadiyanto A. Rachim, Lenny Meilanny. 2017. Tanggungjawab Sosial Perusahaan (CSR) Studi Efektifitas Program PT. Pertamina SEHATI (Sehat Ibu dan Anak Tercinta). Jurnal Penelitian \& PKM, Juli 2017 (4) (2) hal: 129 - 389 ISSN 2442-448x (p), 2581-1126 (e)

Sirait, Khairunnisak Afrini. 2018. Implementasi Corporate Social Responsibility pada perusahaan PT. Anglo Eastern Plantations. Skripsi tidak diterbitkan. Fakultas Ekonomi dan Bisnis Islam. Universitas Islam Negeri Sumatera Utara, Medan

Sudarsana.2018. Tinjauan Teoritis Tentang Implementasi Tanggung Jawab Sosial Perusahaan. Dialektika Masyarakat: Jurnal Sosiologi p (83-103) Vol. 2, No.1, Mei 2018. ISSN: $2615-7500$ 
Suprayitno, Nurillahizazi Winda dan Heru Susilo. 2017. Pengaruh Corporate Social Responsibility (CSR) terhadap Kepuasan Kerja dan Komitmen Organisasi (Penelitian mengenai Internal CSR pada Karyawan PT Pembangkit Jawa-Bali Unit Pembangkitan Paiton). Jurnal Administrasi Bisnis (JAB) | (44) (1) Maret 2017. Hal 127 - 133

Wahyuningrum, Yuniarti dan Irwan Noor, Abdul Wachid. 2013. Pengaruh Program Corporate Social Responsibility Terhadap Peningkatan Pemberdayaan Masyarakat. Jurnal Adminsitrasi Publik, Vol. 1 No. 5, Hal 109 - 115. ISSN: 2503-3867

Wardhana, Panca dan Ainur Rochmaniah. 2015. Opini Masyarakat Terhadap Kegiatan Corporate Social Responsibility PT Pabrik Gula Candi Baru. Jurnal Kanal Vol. 4, No. 1, September 2015, Hal 31 - 44. ISSN: 2302-6790

Triyanto, Dwi. 2013. Pelaksanaan Corporate Social Responsibility (CSR) di Bidang Pendidikan PT. Hino Motors Sales Indonesia (PT. HMSI). Skripsi. Fakultas Teknik. Universitas Negeri Yogyakarta

Triyono, Agus. 2014. Pemberdayaan Masyarakat Melalui Community Development Program Posdaya (Pos Pemberdayaan Keluarga) Pt. Holcim Indonesia Tbk Pabrik Cilacap. KomuniTi, Vol. VI, No. 2 September 2014, h 111 121

Yoo, Dongho and Jieun Lee. 2018. The Effects of Corporate Social Responsibility (CSR) Fit and CSR Consistency on Company Evaluation: The Role of CSR Support. Journal Sustainability.ISSN:2071-1050 www.mdpi.com/journal/sustainability 
https://kominfo.go.id/content/detail/4544/menkominfoluncurkan-lima-program-pemberdayaan-masyarakatbidang-tik/0/sorotan media 


\section{BIODATA PENULIS}

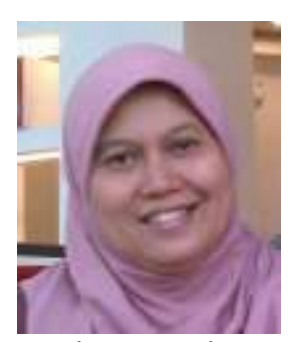

Ainur Rochmaniah., M.Si lahir di Malang, 21 Desember 1969, S1 Ilmu Komunikasi Universitas Muhammadiyah Malang tahun 1993, melanjutkan studi S2 di Prodi Ilmu Komunikasi Universitas Airlangga Surabaya lulus tahun 2009.

Karir pengajaran dimulai tahun 1994 di Fakultas IImu Sosial dan Ilmu Politik Universitas Muhammadiyah Sidoarjo. Penulis terlibat dalam penelitian dan pengabdian kepada masyarakat baik didanai oleh Ristekdikti maupun dana mandiri tentang Komunikasi Organisasi dan Riset Public Relations.

\section{Kukuh Sinduwiatmo., M.Si}

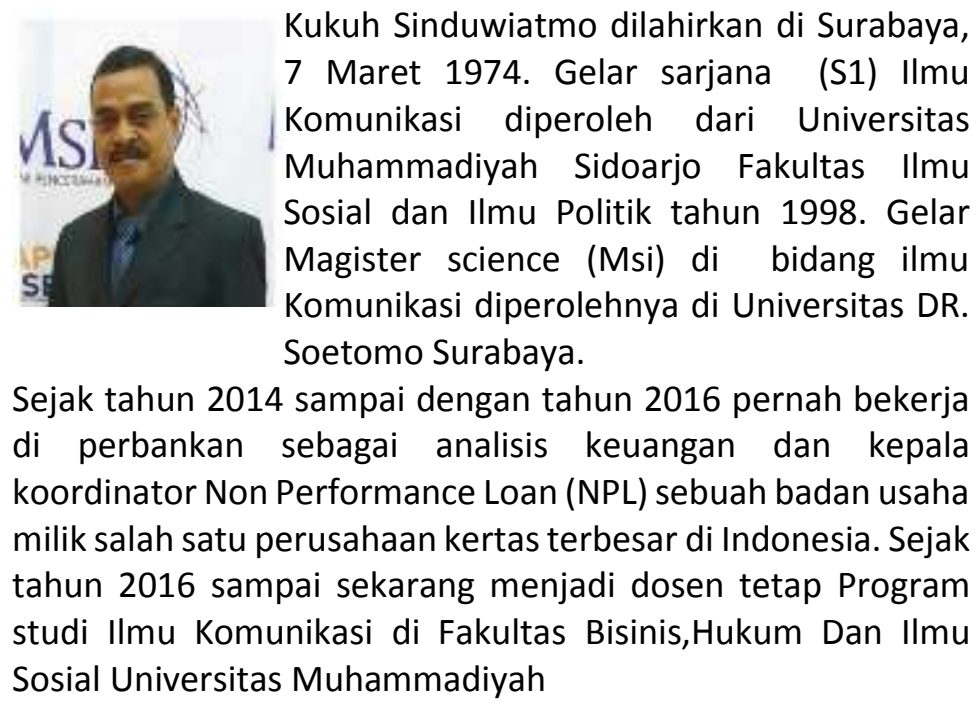

